\title{
Development of an Ultra-Safe, Ultra- Low Emissions Natural Gas Fueled School Bus: Final Report
}

\author{
J.T. Kubesh \\ Southwest Research Institute
}

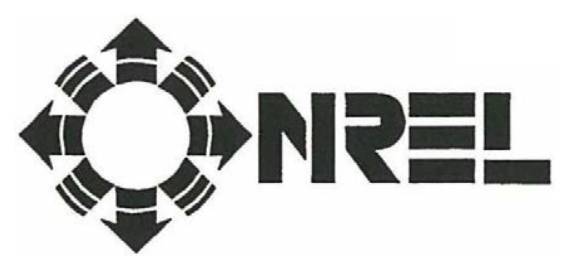

Alternative Fuels Hotline: 1-800-423-1DOE

Alternative Fuels Data Center World Wide Web Site: http://www.afdc.doe.gov

National Renewable Energy Laboratory

1617 Cole Boulevard

Golden, Colorado 80401-3393

A national laboratory of the

U.S. Department of Energy

Managed by the Midwest Research Institute

For the U.S. Department of Energy

Under Contract No. DE-AC36-83CH10093 


\section{NOTICE}

This report was prepared as an account of work sponsored by an agency of the United States government. Neither the United States govemment nor any agency thereof, nor any of their employees, makes any warranty, express or implied, or assumes any legal liability or responsibility for the accuracy, completeness, or usefulness of any information, apparatus, product, or process disclosed, or represents that its use would not infringe privately owned rights. Reference herein to any specific commercial product, process, or service by trade name, trademark, manufacturer, or otherwise does not necessarily constitute or imply its endorsement, recommendation, or favoring by the United States government or any agency thereof. The views and opinions of authors expressed herein do not necessarily state or reflect those of the United States government or any agency thereof.

Available to DOE and DOE contractors from:

Office of Scientific and Technical Information (OSTI)

P.O. Box 62

Oak Ridge, TN 37831

Prices available by calling (423) 576-8401

Available to the public from:

National Technical Information Service (NTIS)

U.S. Department of Commerce

5285 Port Royal Road

Springfield, VA 22161

(703) $487-4650$ 


\title{
Development of an Ultra-Safe, Ultra- Low Emissions Natural Gas Fueled School Bus: Final Report
}

\author{
J.T. Kubesh \\ Southwest Research Institute
}

NREL Technical Monitor: Bill Warnock

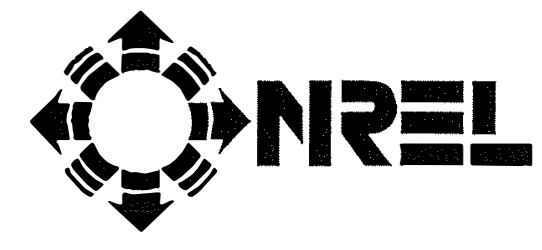

Alternative Fuels Hotline: 1-800-423-1DOE

Alternative Fuels Data Center World Wide Web Site: http://www.afdc.doe.gov

National Renewable Energy Laboratory

1617 Cole Boulevard

Golden, Colorado 80401-3393

A national laboratory of the

U.S. Department of Energy

Managed by the Midwest Research Institute

For the U.S. Department of Energy

Under Contract No. DE-AC36-83CH10093

Prepared under Subcontract Number ZCF-5-13519-01

March 1998 


\section{Executive Summary}

This report documents work conducted under Southwest Research Institute (SwRI) Project 03-6871, "Development of an Ultra-Safe and Low-Emission Dedicated Alternative Fuel School Bus." The project was sponsored by the National RenewableEnergy Laboratory (NREL) under Subcontract No. ZCF-5-13519-01. This report documents Phase III-Integration and Phase-IV Demonstration and serves as the final report for this project. Phase I-Systems Design and Phase II-Prototype Hardware Development were documented in NREL publications TP-425-7609 and TP-425-21081, respectively.

Several significant areas of work are summarized in this report. Integration of the engine technologies developed under Phase II into a production Deere 8.1-L, spark-ignition compressed natural gas engine is detailed, including information on the engine and control system modifications that were made. Federal Test Procedure (FTP) emissions results verifying the ultra-low emissions output of this engine are also included. The informal project goal of producing oxides of nitrogen $\left(\mathrm{NO}_{\mathrm{x}}\right)$ emissions less than or equal to $1.0 \mathrm{~g} / \mathrm{bhp}$-hr over the FTP heavy-duty engine cycle was attained. In addition, a test run that resulted in less than one half of the Ultra-Low Emissions Vehicle limit for $\mathrm{NO}_{x}$ plus non-methane hydrocarbons was obtained. These results were for engine-out (no catalyst) emissions. Results using a catalyst produced very low formaldehyde emissions and virtually zero carbon monoxide and particulate matter emissions. Following these excellent results, a duplicate engine was assembled and integrated into the prototype ultra-safe school bus, the Envirobus 2000. Many of the new and modified subsystems developed during this project for the engine are considered strong candidates for inclusion into the production Deere 8.1-L gas engine in the near future.

A demonstration of the emissions performance and durability of the integrated vehicle was also conducted. Emissions performance of the overall vehicle was quantified through emissions tests conducted while operating on a chassis dynamometer. The overall emissions from the bus (i.e., grams of emission per mile) were found to be very low, especially for a vehicle of this size. The durability of the vehicle was subsequently monitored during a 10,000 mile on-road test. The test was composed of a typical driving cycle, with both stop-and-go and highway driving segments. The bus operated flawlessly throughout this test, with no problems reported by the drivers. The fuel economy was approximately 8.4 miles per gallon on a diesel fuel energy-equivalent basis. The repeat chassis dynamometer tests, subsequent to the road testing, showed that the bus retained its low emissions characteristics throughout the demonstration period. At the conclusion of the project, the Railroad Commission of Texas conducted an independent safety inspection of the bus fuel storage and handling system. The inspectors detected no safety problems in the bus, and made only one minor recommendation for improvement. 


\section{Acknowledgments}

The author would like to thank several key people for their contributions to this project. Daniel Podnar of Southwest Research Institue (SwRI), who was instrumental in the integration and verification of the improved control system features. He was also indispensable in developing the low $\mathrm{NO}_{\mathrm{x}}$ emissions engine calibration during the transient cell tests. Joe Osborne, the SwRI project technician, was an invaluable resource during all phases of the project; without his assistance, the project would not have been as successful. Finally, the author wishes to thank Dr. Kennon Guglielmo, EControls, Inc., who was responsible for adapting the prototype control software and hardware to the production Gas Engine Management electronic control module. His assistance was crucial to the integration process. 


\section{Table of Contents}

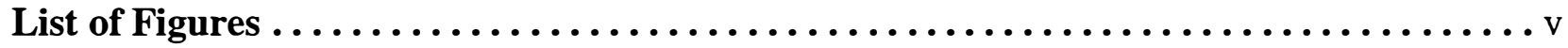
List of Tables $\ldots \ldots \ldots \ldots \ldots \ldots \ldots \ldots \ldots \ldots \ldots \ldots \ldots \ldots \ldots \ldots \ldots \ldots \ldots \ldots$ vi

1.0 Phase III-Integration/Verification $\ldots \ldots \ldots \ldots \ldots \ldots \ldots \ldots \ldots \ldots \ldots$

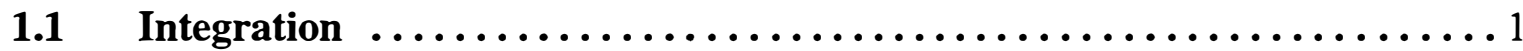

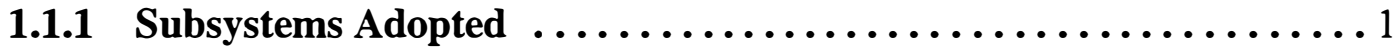

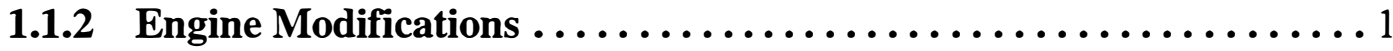

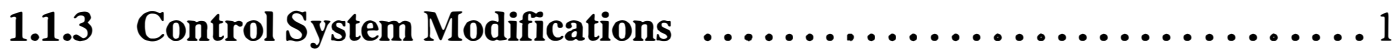

1.1.4 Software Modifications $\ldots \ldots \ldots \ldots \ldots \ldots \ldots \ldots \ldots \ldots \ldots$

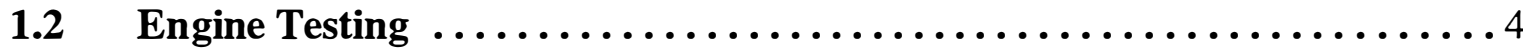

1.2.1 System Troubleshooting $\ldots \ldots \ldots \ldots \ldots \ldots \ldots \ldots \ldots \ldots \ldots \ldots$

1.2.2 Steady-State Emissions Calibration $\ldots \ldots \ldots \ldots \ldots \ldots \ldots \ldots \ldots$

1.2.3 Transient Emissions Testing and Calibration ............... 7

1.2.4 Diagnostics Verification ........................... 17

1.2.5 Final Steady-State Engine Performance $\ldots \ldots \ldots \ldots \ldots \ldots \ldots . \ldots \ldots$

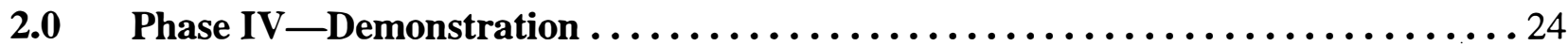

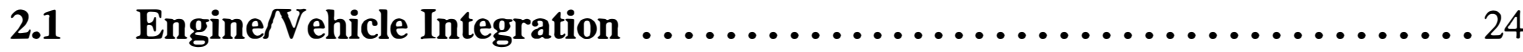

2.1.1 Initial Chassis Dynamometer Tests $\ldots \ldots \ldots \ldots \ldots \ldots \ldots \ldots \ldots \ldots \ldots$

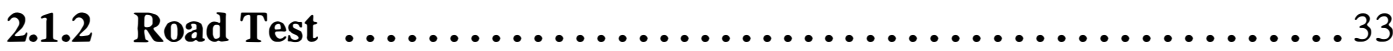

2.1.3 Repeat Chassis Dynamometer Tests $\ldots \ldots \ldots \ldots \ldots \ldots \ldots \ldots$

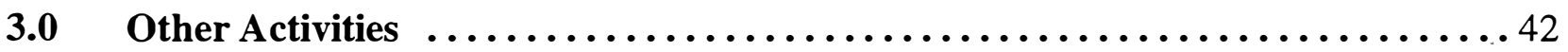

3.1 Railroad Commission of Texas Inspection $\ldots \ldots \ldots \ldots \ldots \ldots \ldots \ldots . \ldots 42$

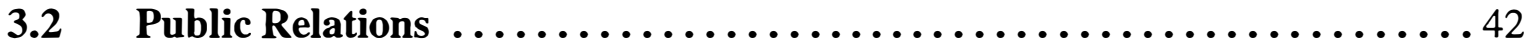

4.0 Conclusions $\ldots \ldots \ldots \ldots \ldots \ldots \ldots \ldots \ldots \ldots \ldots \ldots \ldots \ldots \ldots \ldots \ldots \ldots \ldots, 43$

5.0 Recommendations and Future Study $\ldots \ldots \ldots \ldots \ldots \ldots \ldots \ldots \ldots \ldots \ldots$ 


\section{List of Figures}

Figure

1 Illustration of features found on Deere 8.1-L

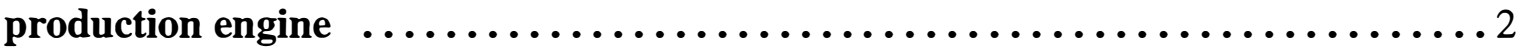

$2 \quad$ Illustration of Deere 8.1-L engine showing new technology and modifications made during this project $\ldots \ldots \ldots \ldots \ldots \ldots \ldots \ldots \ldots \ldots \ldots$

3 Main and auxilliary electronic control modules $\ldots \ldots \ldots \ldots \ldots \ldots \ldots \ldots$

4 Schematic of dual ECM functions and communication $\ldots \ldots \ldots \ldots \ldots \ldots$

5 Estimated FTP cycle emissions results for the NREL version of the 8.1-L engine using the 12 -mode, steady-state prediction $\ldots \ldots \ldots \ldots \ldots \ldots \ldots \ldots$

$6 \quad$ FTP transient-test cycle results $\ldots \ldots \ldots \ldots \ldots \ldots \ldots \ldots \ldots \ldots \ldots \ldots \ldots \ldots$

7 A Comparison of FTP transient test cycle NO $_{x}$ emissions versus BSFC . . . . . . . 14

8 Comparison of FTP test cycle results with ULEV standards $\ldots \ldots \ldots \ldots \ldots \ldots$

9 Results from knock control system test $\ldots \ldots \ldots \ldots \ldots \ldots \ldots \ldots \ldots \ldots$

10 Results from misfire control system test $\ldots \ldots \ldots \ldots \ldots \ldots \ldots \ldots \ldots \ldots$

11 Results for surge suppression system with system disabled . . . . . . . . . . 22

12 Results for surge suppression system with system enabled $\ldots \ldots \ldots \ldots \ldots \ldots$

13 Modified test engine as installed in Envirobus $2000 \ldots \ldots \ldots \ldots \ldots \ldots \ldots \ldots$

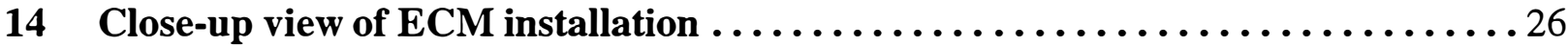

15 Envirobus 2000 under test at chassis dynamometer facility $\ldots \ldots \ldots \ldots \ldots \ldots$

16 Plot of engine speed and throttle position for heavy-duty

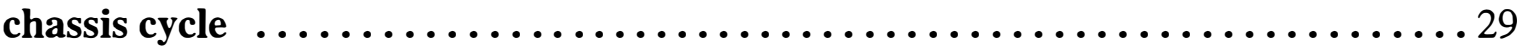

17 Plot of engine speed and throttle position for central business

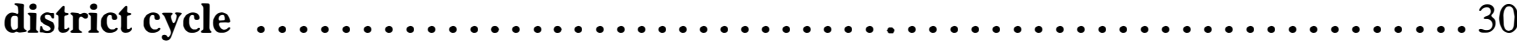

18 Comparison of emissions results for heavy-duty chassis cycle tests $\ldots \ldots \ldots \ldots 31$

19 Comparison of emissions results for central business district tests $\ldots \ldots \ldots \ldots 32$ 


\section{List of Figures (Continued)}

Figure

$\underline{\text { Page }}$

20 Driving route followed by bus during demonstration test $\ldots \ldots \ldots \ldots \ldots \ldots . \ldots 34$

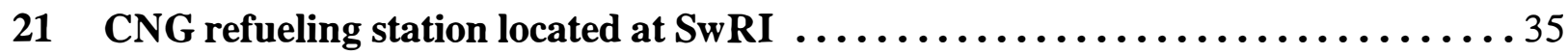

22 Comparison of emissions results for HDCC cold-start tests before and after the demonstration test $\ldots \ldots \ldots \ldots \ldots \ldots \ldots \ldots \ldots \ldots \ldots \ldots \ldots \ldots$

23 Comparison of emissions results for HDCC hot-start tests before

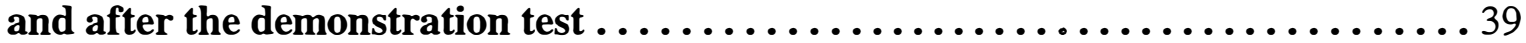

24 Comparison of emissions resultsfor CBD hot-start tests before

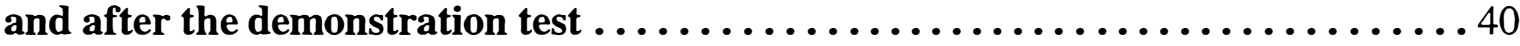




\section{List of Tables}

$\underline{\text { Table }}$

Page

1 CARB certification fuel gas composition $\ldots \ldots \ldots \ldots \ldots \ldots \ldots \ldots \ldots \ldots$

2 Transient test cycle summary $\ldots \ldots \ldots \ldots \ldots \ldots \ldots \ldots \ldots \ldots \ldots \ldots \ldots \ldots \ldots$

3 Cold-hot composite test results (no catalyst) $\ldots \ldots \ldots \ldots \ldots \ldots \ldots \ldots \ldots \ldots \ldots$

$4 \quad$ FTP transient cycle test results $($ hot starts) $\ldots \ldots \ldots \ldots \ldots \ldots \ldots \ldots \ldots \ldots$

5 Emissions level comparison (units-g/bhp-hr) $\ldots \ldots \ldots \ldots \ldots \ldots \ldots \ldots \ldots$

6 Summary of $\mathrm{HCHO}$ emissions data $\ldots \ldots \ldots \ldots \ldots \ldots \ldots \ldots \ldots \ldots \ldots$

7 Full-load engine performance-final engine calibration $\ldots \ldots \ldots \ldots \ldots \ldots$

8 Chassis dynamometer emissions test results $\ldots \ldots \ldots \ldots \ldots \ldots \ldots \ldots \ldots \ldots$

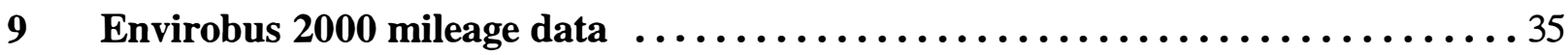

10 Repeat chassis dynamometer emissions results $\ldots \ldots \ldots \ldots \ldots \ldots \ldots \ldots$

11 Comparison of chassis dynamometer $\mathrm{NO}_{\mathrm{x}}$ emissions results $\ldots \ldots \ldots \ldots \ldots \ldots$ 


\subsection{Phase III-Integration/Verification}

\subsection{Integration}

Integration included evaluation of the various engine modifications and advanced technologies developed in Phase II-Prototype Hardware Development [see the National Renewable Energy Laboratory (NREL) Publication No. TP-425-21081] and selecting the most promising of these for incorporation in a test engine. The engine was then subjected to a series of tests to determine its emissions and efficiency potential.

\subsubsection{Subsystems Adopted}

Four major subsystems from the Phase II development work were adopted for use in the bus engine. These subsystems included the humidity compensation system, the surge suppression system, and the knock and misfire detection and control systems. These four new subsystems are not readily available as part of on-highway natural gas engines, and their inclusion into the prototype Deere 8.1$\mathrm{L}$ engine developed during this project is a definite advance in the state of the art.

The very successful model-based or observer-type air/fuel-ratio control that was developed was not adopted, because the production Gas Engine Management (GEM) engine controller uses an enhanced speed-density air/fuel ratio control strategy that works quite well, and the amount of software development required to implement the new observer code was believed to be prohibitive in terms of cost and time. Excessive execution time in the microcontroller for these complex calculations was also a concern.

\subsubsection{Engine Modifications}

The engine configuration was unchanged from the configuration at the end of the Phase II development work. The engine is an in-line six-cylinder model with a displacement of 8.1 liters (L). A spark-ignited, lean-burn, turbocharged, aftercooled combustion system is used. The engine has full electronic control of fueling, spark timing, boost pressure, and throttle position. Figure 1 is a schematic representation of the features of the baseline production Deere 8.1-L engine. A schematic, which details the design modifications made to the engine during Phase $I$, is shown in Figure 2.

\subsubsection{Control System Modifications}

The engine control system was converted from the Southwest Research Institute (SwRI) designed Rapid Prototyping Engine Control System (RPECS) used in Phase II to a modified version of the production Mesa Environmental GEM system. Performance testing of the engine was conducted to determine that the control system was operating correctly. After this shakedown period, the GEM system was modified to reflect the Phase II configuration. The pre-turbine and exhaust back-pressure sensors were eliminated from the engine control system during Phase II. The pre-turbine pressure sensor was replaced by a pressure sensor upstream of the throttle, termed the pre-throttle pressure. A calculated back-pressure estimate based on the mass flow through the exhaust was adopted in place of the exhaust back-pressure sensor. 


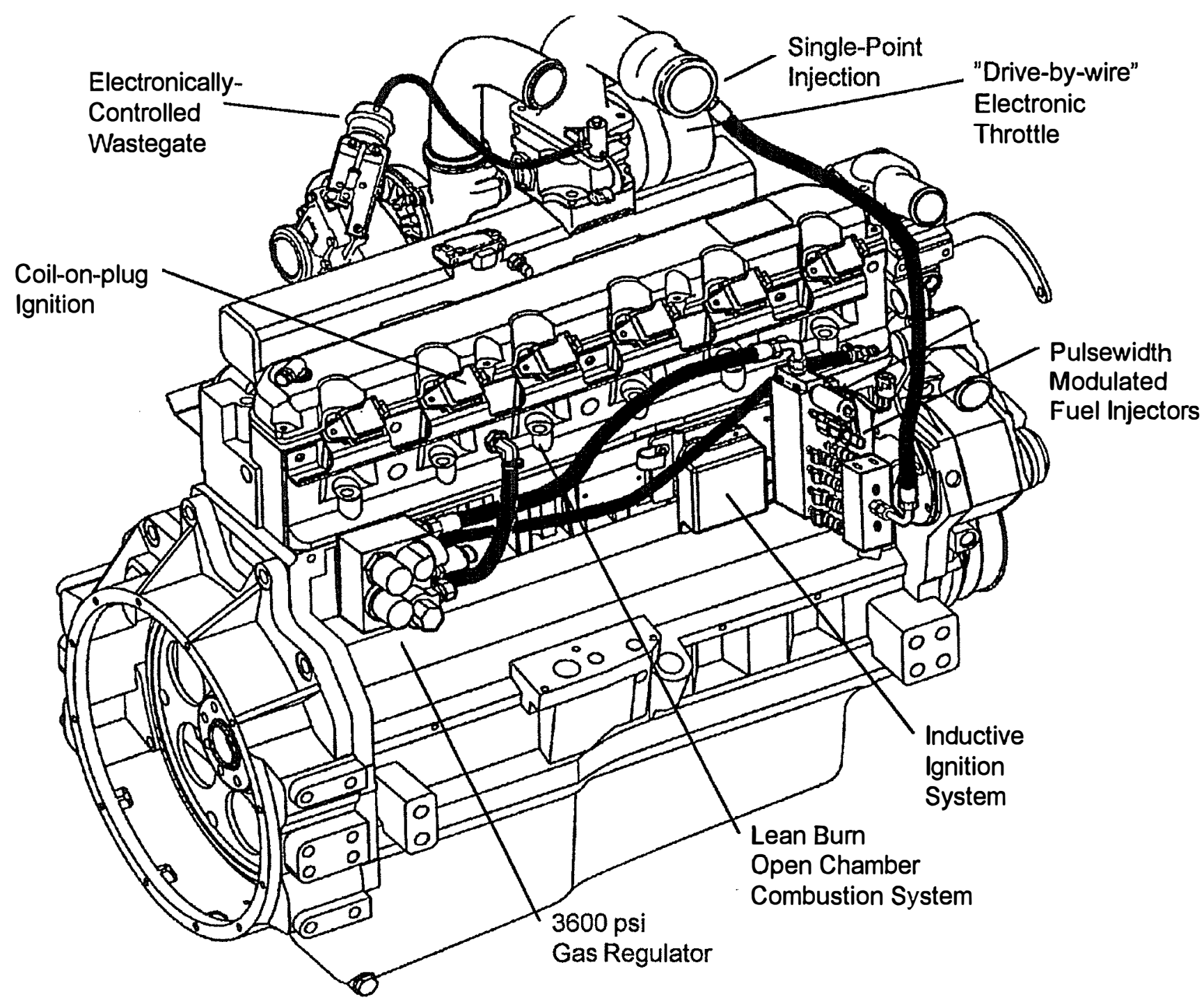

Figure 1. Illustration of features found on Deere 8.1-L production engine 


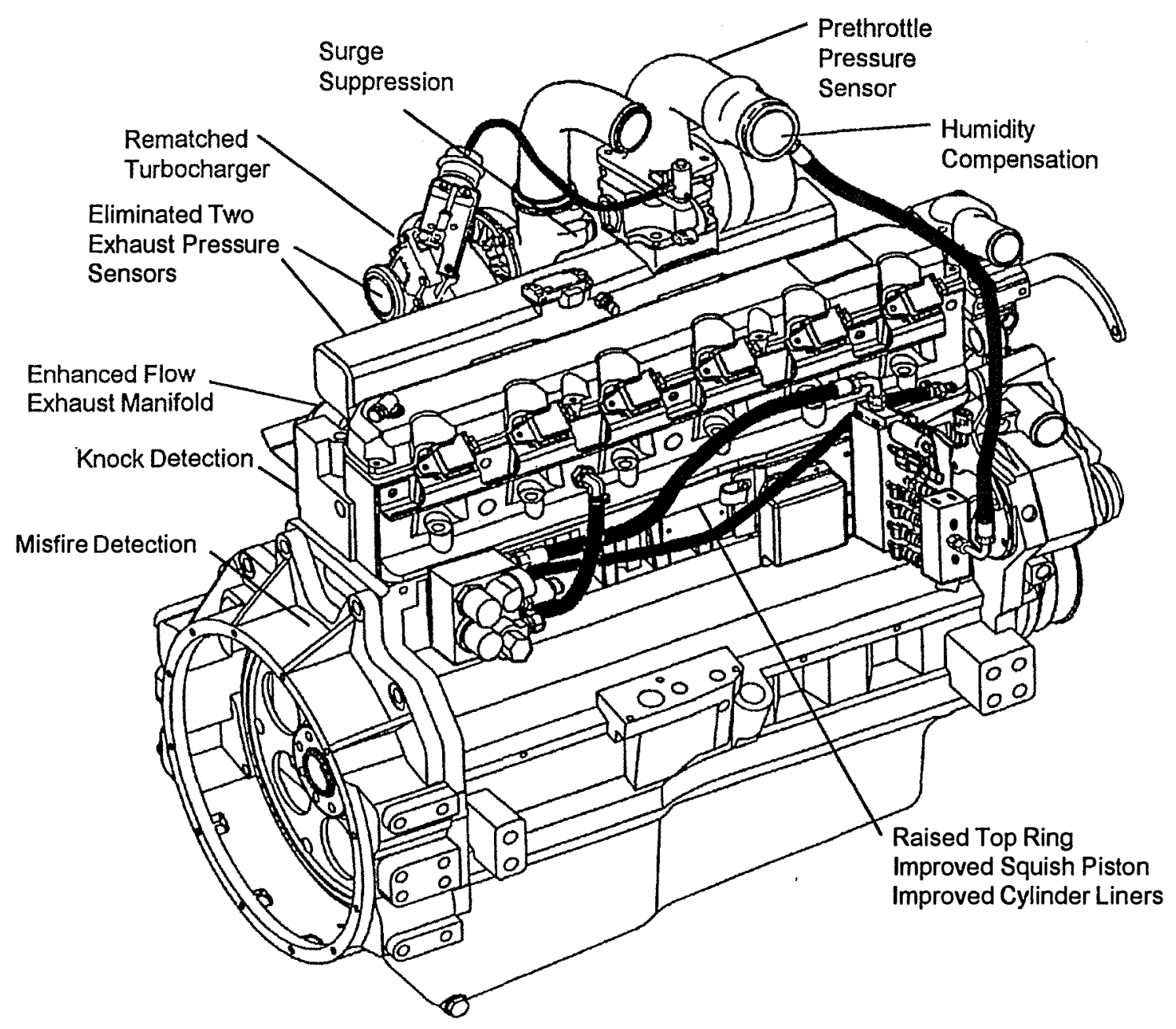

Figure 2. Illustration of Deere 8.1L engine showing new technology and modifications made during this project 
The control system electronics developed during Phase II were mounted in an auxiliary electronics package that was constructed using two of the existing GEM modules. One of the modules was an empty shell and was used to mount the knock and misfire signal-conditioning electronics. The other module was a fully functional GEM electronic control module (ECM); this ECM was used for controlling the knock and misfire detection systems and the humidity compensation system, as well as for communication with the main ECM. Figure 3 is a photograph of the finished modules. The auxiliary module has been opened to provide a view of the control electronics for knock and misfire detection developed by SwRI.

The new auxiliary module was designed to work with the existing ECM in the following manner. The auxiliary module would detect misfire, knock, or humidity changes. The unit would then calculate the required changes to the engine calibration in order to eliminate knock or misfire, or compensate for the change in humidity. These changes in engine calibration would be in terms of percentage changes to the fuel/air equivalence ratio, spark timing, and boost pressure setpoints. These setpoints would then be transferred to the main ECM over a serial communications link. The main ECM would then apply these calibration multipliers to the desired operating setpoints. An additional piece of information supplied by the auxiliary ECM was the universal exhaust gas oxygen (UEGO) sensor calibration shift due to humidity. This shift was calculated, and the predicted offset in the exhaust equivalence ratio, as measured by the UEGO sensor, was supplied to the main ECM. Figure 4 is a schematic of the dual ECM configuration and the information transfer that occurs. The auxiliary module also supplied the threshold voltage for the misfire detection circuit. The RPECS controller had provided an analog output as a reference to the misfire detection unit circuitry, but the GEM ECM does not have any analog outputs. A pulse-width modulated (PWM) output from the auxiliary GEM module was low pass-filtered and buffered to supply an analog voltage to the misfire detector's threshold input.

\subsubsection{Software Modifications}

The control software developed with the RPECS during Phase II was written in "C" using floating point arithmetic on an IBM-PC platform. To adapt this software for use in the production controller, which uses a Motorola 68HC11 microcontroller, the control algorithms were translated in terms of assembly language code using integer arithmetic. This task was conducted by EControls, Inc., the firm that develops all of the software for the Mesa Environmental GEM and also serves as a consultant for SwRI.

\subsection{Engine Testing}

\subsubsection{System Troubleshooting}

The new control sof tware incorporated all of the new subsystems discussed above and illustrated in Figure 4. A preliminary version of the software was completed by EControls, Inc. The sof tware was tested in conjunction with the modified ECM in a bench test prior to installation on the engine, to ensure the software was functioning correctly. Following the bench test, the main and auxiliary ECM units were reinstalled on the engine, and the new software was loaded. 


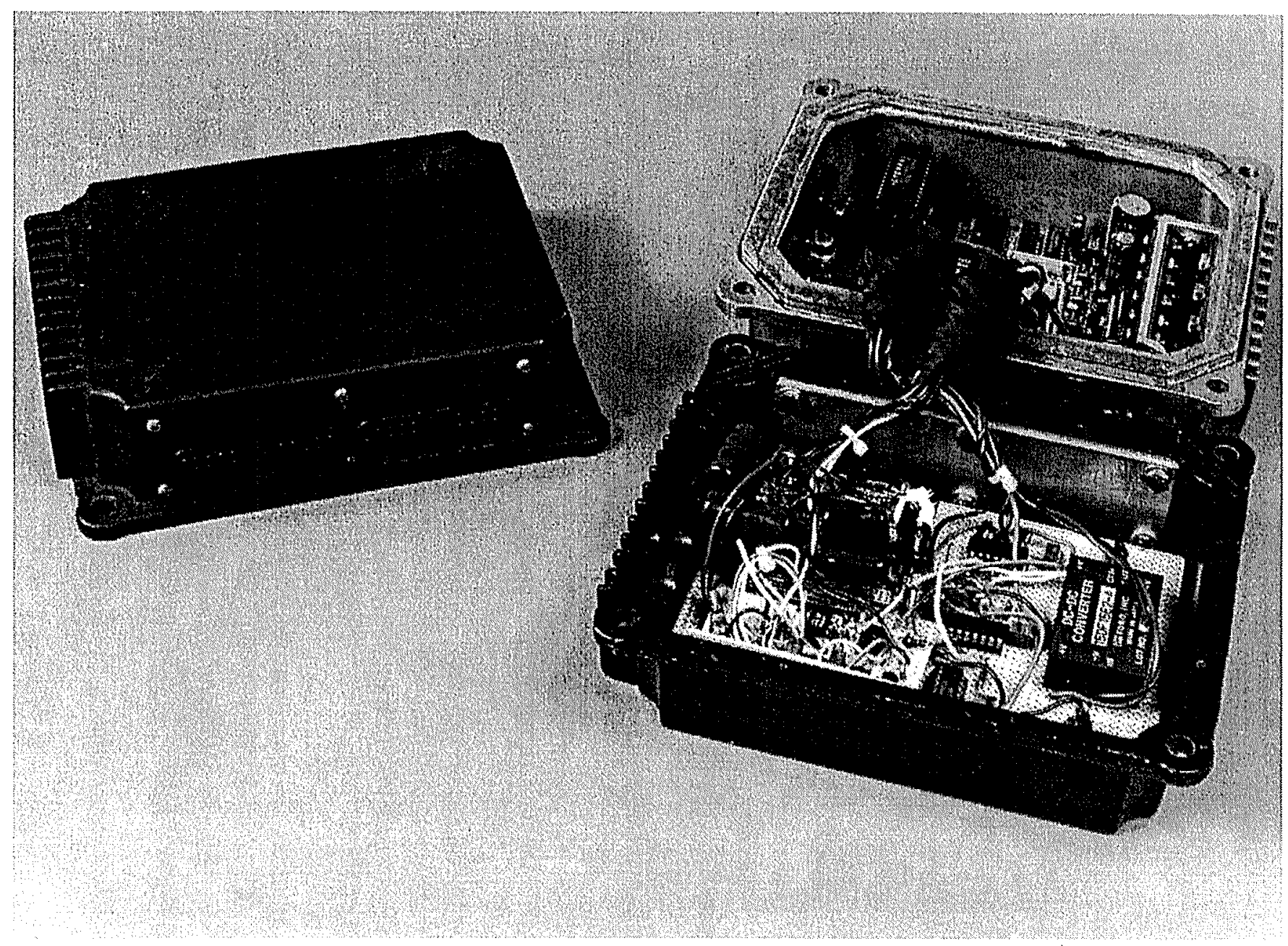

Figure 3. Main and auxiliary electronic control modules 


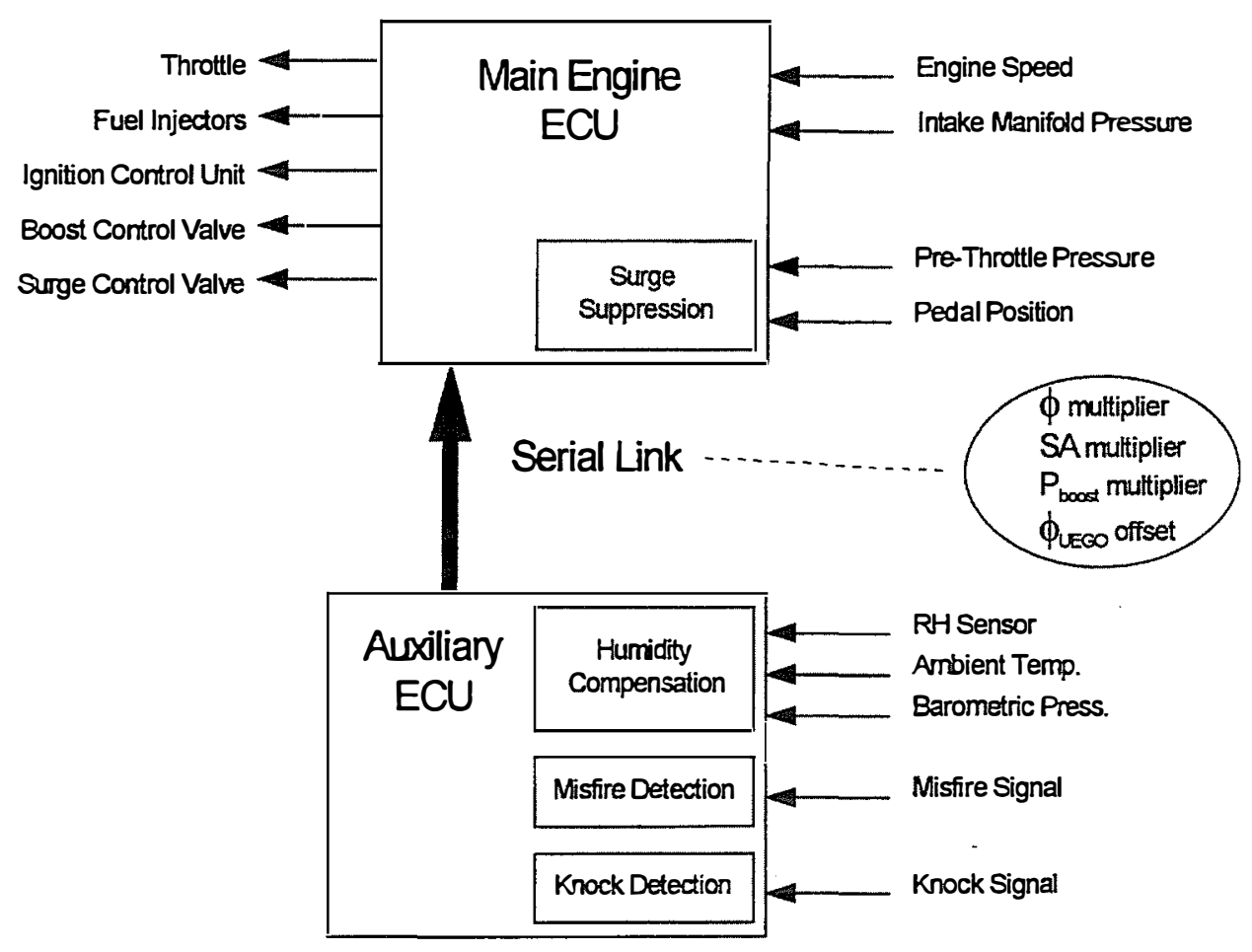

Figure 4. Schematic of dual ECM functions and communication

Debugging of the system required a large-scale effort to ensure that all of the major functional improvements (i.e., humidity compensation, knock and misfire detection, and surge suppression) were working. Most of the work was done to fix problems that occurred with the knock and misfire detection systems. Electromagnetic interference (EMI or noise) generated by the ignition system caused erroneous triggering of the knock and misfire detection systems. In particular, the magnetostrictive knock sensor revealed itself to be quite sensitive to radiated noise. The option of substituting a piezoelectric knock sensor was considered, but SwRI decided that this would be pursued only if the noise problem was insurmountable. Improved shielding and grounding was used to improve most of the noise problems, although the auxiliary ECM had to be modified to help fix the problems encountered with the misfire detection system. Since system input noise was triggering false misfire indications, the signals were rerouted through an additional signal-conditioning circuit on the auxiliary ECM board. This fix was tested and found to reduce the number of false triggers substantially. Testing of the enhanced surge suppression software proved that the new system could control surge with performance similar to the RPECS system.

\subsubsection{Steady-State Emissions Calibration}

A low-emissions calibration was developed for the engine based on steady-state testing. A 12-mode emissions test, used to predict transient-cycle emissions results, was conducted. This test was required due to the significant changes in engine configuration that were made compared to the production engine. The results provide an estimate of the oxides of nitrogen $\left(\mathrm{NO}_{\mathrm{x}}\right)$, carbon monoxide (CO), and total hydrocarbon (THC) emissions. These results were used to guide further changes to the engine calibration in order to meet the informal project goal of 1.0 grams per brake 
horsepower hour (g/bhp-hr) $\mathrm{NO}_{\mathrm{x}}$. A summary of these results from the final steady-state engine calibration is shown in Figure 5. The estimate of the $\mathrm{NO}_{\mathrm{x}}$ emissions was $1.0 \mathrm{~g} / \mathrm{bhp}-\mathrm{hr}$, equal to the informal project goal. Also, the $\mathrm{NO}_{x}$ plus non-methane hydrocarbon (NMHC) estimate is approximately $1.47 \mathrm{~g} / \mathrm{bhp}-\mathrm{hr}$, assuming that the NMHC fraction is 15 percent of the total $\mathrm{HC}$ number. Note that this estimate is for engine-out emissions under steady-state conditions, and these estimates are usually considered to be the best achievable emission levels. In other words, depending on the success of the transient-testing development program, the 12-mode prediction approximates the lowest emission levels that can be attained.

\subsubsection{Transient Emissions Testing and Calibration}

\subsubsection{Test Preparations}

Following completion of the steady-state calibration and control system debugging programs, the engine was transferred to a test cell at the SwRI Emissions Research Laboratory. This test cell was capable of running the heavy-duty federal test procedure (FTP) transient test and was equipped with a full-dilution tunnel and the required emissions measurement equipment. All testing was conducted using a fuel gas blend which corresponds to California Air Resources Board (CARB) certification specifications. This gas had the nominal composition shown in Table 1.

\section{Table 1. CARB certification fuel gas composition}

\begin{tabular}{||l|c|}
\hline \multicolumn{1}{|c|}{ Gas Constituent } & Concentration (\%) \\
\hline \hline Methane & 90.5 \\
\hline Ethane & 4.0 \\
\hline Propane & 2.0 \\
\hline Nitrogen & 3.5 \\
\hline
\end{tabular}

Initial work in the transient cell focused on troubleshooting minor setup problems and verifying that the engine was operating correctly. A major area of concern was verifying that the engine was operating at the correct fuel/air equivalence ratio $(\phi)$. The UEGO sensor used to control $\phi$ is sensitive to changes in the pressure of the exhaust stream, and the engine exhaust system had been changed during installation in the transient cell. On a production Deere engine, this would not be a problem since the engine would be equipped with an exhaust pressure sensor that the controller would use to compensate for exhaust back-pressure changes. The NREL engine does not have exhaust pressure sensors and instead relies on a calculated exhaust back-pressure estimate. This estimation scheme works well in the bus application, but the exhaust system in the test cell was different than that seen on the bus. Therefore, the exhaust back pressure in the transient cell would not likely match the estimated pressure, and this difference would cause the UEGO sensor calibration to shift. However, since the transient test cell directs the engine exhaust into a dilution 


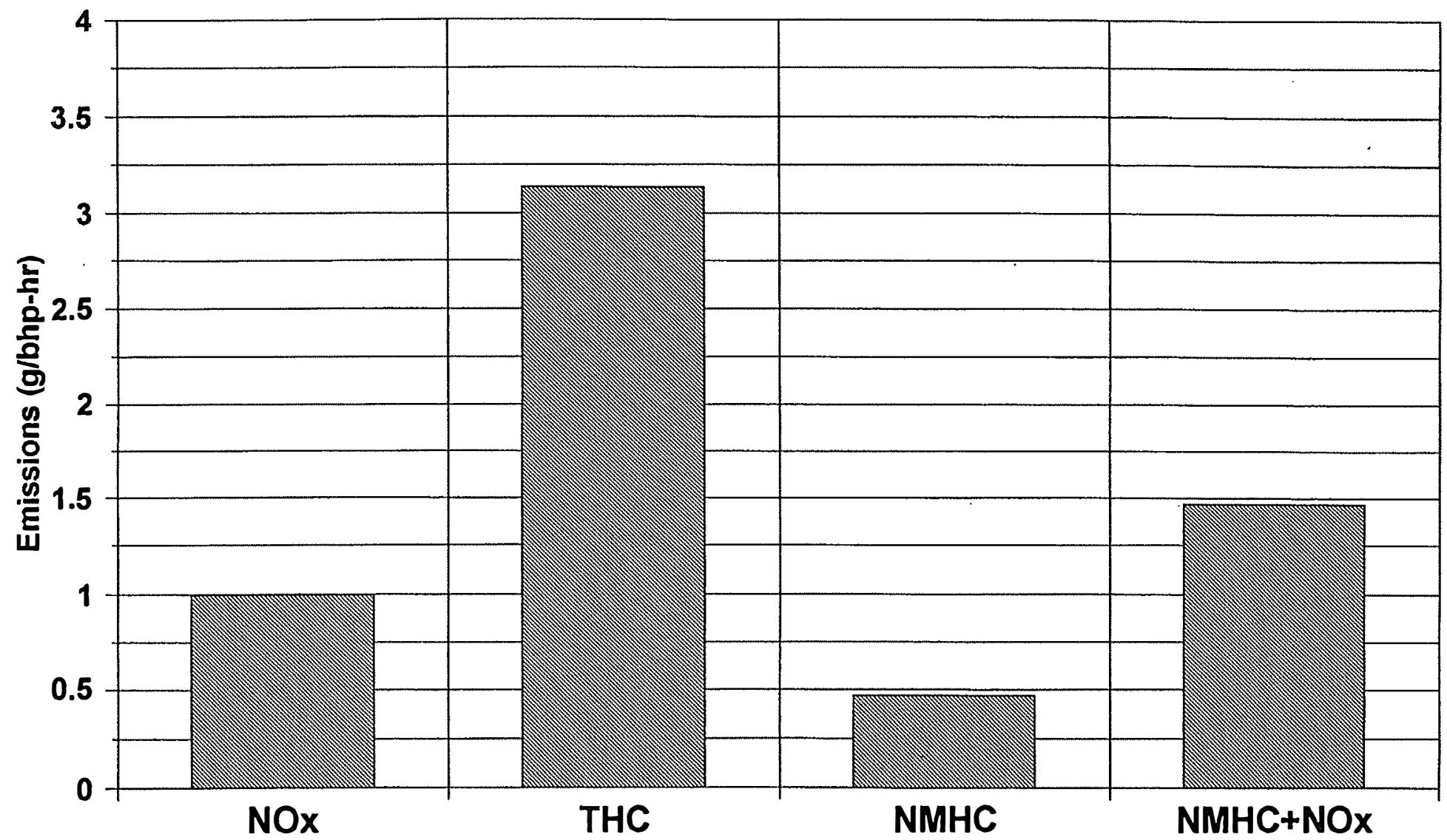

Figure 5. Estimated FTP cycle emissions results for the NREL version of the 8.1-L engine using the 12-mode, steady-state prediction 
tunnel, a direct way to measure $\phi$ was not possible. Steady-state test data were used to set the proper back pressure within the exhaust system. Following this, the exhaust back-pressure estimate was compared to the actual exhaust pressure and was found to be slightly high. The UEGO $\phi$ offset table in the humidity compensation software was modified to correct for the shift in UEGO $\phi$ calibration resulting from the difference in pressures. The correct $\phi$ was determined by operating the engine at idle, torque peak, and rated power conditions, and then changing the UEGO $\phi$ offset to match the power output and pre-turbine exhaust temperatures to the steady-state data records.

\subsubsection{Test Sequence}

During most of the test sequence, the knock, misfire, and humidity compensation systems were disabled. This was done to prevent any potential problems within these prototype systems from jeopardizing the results of the overall calibration process. For example, if the misfire system malfunctioned and began indicating a large number of misfires, the resultant enrichment of the fuel/air mixture would lead to much higher $\mathrm{NO}_{\mathrm{x}}$ emissions. These higher $\mathrm{NO}_{\mathrm{x}}$ emissions might be wrongly interpreted as the result of an engine calibration change instead of a system problem, thereby moving the calibration process in the wrong direction.

A total of 28 transient tests were completed during the test program. Table 2 contains a summary of the tests conducted, including information regarding the type of cycle run, and a short description of the purpose or results of each test.

\subsubsection{Test Results}

The first practice cycle to run and pass the cycle-matching statistics had initial results that were very promising, with $\mathrm{NO}_{\mathrm{x}}$ emissions at approximately $1.33 \mathrm{~g} / \mathrm{bhp}-\mathrm{hr}$ and total hydrocarbon emissions at approximately $5.0 \mathrm{~g} / \mathrm{bhp}-\mathrm{hr}$. These results were obtained with an engine calibration that was somewhat different from that developed in the steady-state mapping program. The spark timing map was unchanged, but slight enrichment of the equivalence ratio map was required over the high and medium load portions of the engine operating range. This was done to eliminate the possibility of misfire during the early calibration effort. The maximum boost pressure limits were also reduced slightly to reflect the increased power output due to the enrichment. Since these initial results were very good, this calibration was used as the basis for all future transient work.

Typically, transient results are reported in terms of a composite value, i.e., a weighted average of the cold- and hot-start values. For example, the composite brake specific $\mathrm{NO}_{\mathrm{x}}\left(\mathrm{BSNO}_{\mathrm{x}}\right)$ emissions value is calculated using the following formula:

$$
\mathrm{BSNO}_{\mathrm{x}(\text { Composite })}=1 / 7 * \mathrm{BSNO}_{\mathrm{x}(\text { Cold-Stan })}+6 / 7 * \mathrm{BSNO}_{\mathrm{x}(\text { Hot-Start })}
$$

A cold-start/hot-start sequence was run to determine the composite emissions level for engine-out emissions with no catalyst. The engine slightly exceeded the limits set on the torque and power regressions and did not pass cycle statistics validation on the cold start (run 5C). This failure to meet the cycle statistics was largely a function of the test cell control system. Since the engine was operating quite well, SwRI decided that this cold start could be used for comparison purposes. The following hot start $(5 \mathrm{H})$ passed cycle statistics, and the two runs were used to calculate the composite value. 
Table 2. Transient test cycle summary

\begin{tabular}{|c|c|c|c|}
\hline $\begin{array}{l}\text { Cycle } \\
\text { No. }\end{array}$ & $\begin{array}{l}\text { Test } \\
\text { No. }\end{array}$ & $\begin{array}{l}\text { Cycle } \\
\text { Type }\end{array}$ & Test Description \\
\hline 1 & $1 \mathrm{H}$ & Hot Start & First test cycle to pass statistics \\
\hline 2 & & Hot Start & Volumetric efficiency and spark-timing calibration changes \\
\hline 3 & & Hot Start & Spark-timing, equivalence-ratio calibration changes \\
\hline 4 & & Hot Start & Volumetric efficiency calibration changes \\
\hline 5 & $2 \mathrm{H}$ & Hot Start & Spark-timing, equivalence-ratio calibration changes \\
\hline 6 & & Hot Start & Spark-timing, equivalence-ratio calibration changes \\
\hline 7 & & Hot Start & Spark, equivalence ratio, idle compensation changes \\
\hline 8 & $3 \mathrm{H}$ & Hot Start & First test cycle "for the record" \\
\hline 9 & & Hot Start & Spark-timing calibration change \\
\hline 10 & $4 \mathrm{H}$ & Hot Start & Combustion air dew point temperature too high \\
\hline 11 & & Cold Start & Practice cold start with $4 \mathrm{H}$ calibration \\
\hline 12 & $4 \mathrm{HB}$ & Hot Start & First good $1.0 \mathrm{~g} / \mathrm{bhp}-\mathrm{hr} \mathrm{NO}$ cycle \\
\hline 13 & $4 \mathrm{HC}$ & Hot Start & Repeat $1.0 \mathrm{~g} / \mathrm{bhp}-\mathrm{hr} \mathrm{NO}_{\mathrm{x}}$ cycle \\
\hline 14 & & Hot Start & Adaptive table calibration changes \\
\hline 15 & & Hot Start & Knock/misfire sensor test \\
\hline 16 & & Hot Start & Humidity compensation test \\
\hline 17 & $4 \mathrm{HD}$ & Hot Start & Humidity compensation test- $\mathrm{RH}$ sensor drifted high \\
\hline 18 & $5 \mathrm{C}$ & Cold Start & Slightly high torque/power regression slopes \\
\hline 19 & $5 \mathrm{H}$ & Hot Start & Hot start for composite calculation with 5C \\
\hline 20 & & Hot Start & Installed catalyst, practice cycle \\
\hline 21 & $6 \mathrm{HA}$ & Hot Start & First run with catalyst \\
\hline 22 & $7 \mathrm{C}$ & Cold Start & Force-cooled engine \\
\hline 23 & $7 \mathrm{HA}$ & Hot Start & Slightly high speed-regression slope \\
\hline 24 & $7 \mathrm{HB}$ & Hot Start & Repeat of 7HA with improved cell control \\
\hline 25 & $8 \mathrm{C}$ & Cold Start & Good cold start for composite record \\
\hline 26 & $8 \mathrm{H}$ & Hot Start & Good hot start for composite record \\
\hline 27 & & Hot Start & Spark-timing calibration change-practice cycle \\
\hline 28 & 9HA & Hot Start & Lowest $\mathrm{NO}_{\mathrm{x}}$ cycle \\
\hline
\end{tabular}


The initial cold start for the catalyst-equipped tests was marred because of a failure in the battery charger system in the test cell; this caused an unacceptably low battery voltage and resulted in poor engine performance. The test was aborted early, and the engine was then force-cooled to lower the oil and water temperatures to nearly cold-start levels. A cold-start/hot-start sequence, runs 7C and 7HA, was conducted following the force cooling. The cold start passed cycle statistics. However, due to a change in test cell control parameters by the test cell engineer in an attempt to improve cycle tracking, the subsequent hot start failed. The control parameters were changed back, and another hot start was run. This run, 7HB, passed statistics, and the data from runs 7C and 7HB were used in calculating the composite value. Due to the problems encountered, this composite value should be used for comparison purposes only and not be considered as an official test.

A final cold-start/hot-start sequence, runs $8 \mathrm{C}$ and $8 \mathrm{H}$, was conducted on the following day. This sequence passed the cycle statistics on both the cold and hot starts. The composite emissions levels for this sequence are shown below in Table 3. These tests went quite well, with the exception of the particulate matter (PM) measurement on the cold start. A $0.140 \mathrm{~g} / \mathrm{bhp}-\mathrm{hr}$ particulate level was measured, which is roughly seven times the results for previous cold starts. Since the following hot start yielded particulate emissions of $0.026 \mathrm{~g} / \mathrm{bhp}-\mathrm{hr}$, a very reasonable level for a hot start, the coldstart data point was considered to be an outlier. A value of $0.020 \mathrm{~g} / \mathrm{bhp}-\mathrm{hr}$, which was equal to that obtained from cold-start run $5 \mathrm{C}$, was assumed for the composite calculation.

Table 3. Cold-hot composite test results (no catalyst)

\begin{tabular}{||l|c|c||}
\hline \multicolumn{1}{|c|}{ Parameter } & Results & Units \\
\hline \hline $\mathrm{NO}_{\mathrm{x}}$ & 1.009 & $\mathrm{~g} / \mathrm{bhp}-\mathrm{hr}$ \\
\hline $\mathrm{THC}$ & 4.931 & $\mathrm{~g} / \mathrm{bhp}-\mathrm{hr}$ \\
\hline $\mathrm{NMHC}$ & 0.420 & $\mathrm{~g} / \mathrm{bhp}-\mathrm{hr}$ \\
\hline $\mathrm{CO}$ & 1.768 & $\mathrm{~g} / \mathrm{bhp}-\mathrm{hr}$ \\
\hline $\mathrm{PM}$ & $0.025^{*}$ & $\mathrm{~g} / \mathrm{bhp}-\mathrm{hr}$ \\
\hline $\mathrm{BSFC}$ & 0.413 & $\mathrm{lb} / \mathrm{bhp}-\mathrm{hr}$ \\
\hline \hline * Estimate due to outlier data on cold-start \\
\hline \hline
\end{tabular}

Results of several hot starts were also analyzed to determine the ability of the engine to repeatably obtain the low $\mathrm{NO}_{x}$ results. The results of four hot-start test cycles $(4 \mathrm{HB}, 4 \mathrm{HC}, 5 \mathrm{H}, 7 \mathrm{HB})$ were averaged and compared. These four hot-start cycles all passed the cycle statistics criteria, and $\mathrm{NO}_{x}$, THC, NMHC, CO, and PM were measured. The engine used virtually identical engine calibrations on these cycles, and it was not equipped with a catalyst. These data are referred to as the average cycle, and are summarized in Table 4. In addition, data for test cycles that produced the lowest $\mathrm{NO}_{\mathrm{x}}$ and BSFC, obtained during the test program, are included. 
Table 4. FTP transient-cycle test results (hot starts)

\begin{tabular}{|c|c|c|c|c|}
\hline Parameter & $\begin{array}{c}\text { Average } \\
\text { Cycle }\end{array}$ & $\begin{array}{c}\text { Lowest } \\
\text { NO }_{x} \text { Cycle }\end{array}$ & $\begin{array}{c}\text { Lowest } \\
\text { BSFC Cycle }\end{array}$ & Units \\
\hline $\mathrm{NO}_{\mathrm{x}}$ & 1.000 & 0.767 & 1.130 & g/bhp-hr \\
\hline THC & 4.827 & 5.590 & 4.357 & $\mathrm{~g} / \mathrm{bhp}-\mathrm{hr}$ \\
\hline NMHC & 0.494 & 0.451 & 0.489 & g/bhp-hr \\
\hline $\mathrm{CO}$ & 1.751 & 1.857 & 1.675 & g/bhp-hr \\
\hline PM & 0.021 & 0.023 & 0.016 & g/bhp-hr \\
\hline BSFC & 0.403 & 0.419 & 0.389 & $\mathrm{lb} / \mathrm{bhp}-\mathrm{hr}$ \\
\hline
\end{tabular}

In terms of emissions, the informal project goal of $1.0 \mathrm{~g} / \mathrm{bhp}-\mathrm{hr} \mathrm{NO}_{\mathrm{x}}$ was met based on the average cycle, and the low $\mathrm{NO}_{\mathrm{x}}$ test was well below the goal. The THC and NMHC levels shown are lower than competitive engines, especially for this $\mathrm{NO}_{x}$ level. Also, note that these emission levels are engine-out emissions; further reductions in these quantities could be expected with the use of an effective oxidation catalyst. Data from Table 4 on the average and lowest $\mathrm{NO}_{\mathrm{x}}$ cycles are also illustrated in Figure 6.

Brake-specific fuel consumption (BSFC), the ratio of the mass of fuel consumed during the test cycle to the work produced by the engine during the test cycle, is included in the table to indicate the relative efficiency of the engine. The lowest BSFC number for a single FTP hot-start test was measured at $0.389 \mathrm{lb} / \mathrm{bhp}-\mathrm{hr}$. For this test, the $\mathrm{NO}_{\mathrm{x}}$ emissions were $1.130 \mathrm{~g} / \mathrm{bhp}-\mathrm{hr}$. This is an excellent combination of both low $\mathrm{NO}_{\mathrm{x}}$ emissions and low BSFC over the FTP cycle; however, the $\mathrm{NO}_{x}$ emissions were slightly higher than the informal project goal. The average cycle BSFC was $0.403 \mathrm{lb} / \mathrm{bhp}$-hr. This is excellent for any on-highway compressed natural gas (CNG) engine, since production medium-duty engines with similar emissions levels have a BSFC number that is typically 0.43-0.46. The average cycle $\mathrm{NO}_{\mathrm{x}}$ emissions were $1.000 \mathrm{~g} / \mathrm{bhp}-\mathrm{hr}$. When comparing the average cycle to the lowest BSFC cycle, the reduction in $\mathrm{NO}_{\mathrm{x}}$ emissions, coupled with an associated rise in $\mathrm{BSFC}$, is typical of gas engines. The BSFC for the lowest $\mathrm{NO}_{\mathrm{x}}$ cycle was increased further to 0.419 $\mathrm{lb} / \mathrm{bhp}-\mathrm{hr}$, while $\mathrm{NO}_{\mathrm{x}}$ emissions dropped to $0.767 \mathrm{~g} / \mathrm{bhp}-\mathrm{hr}$. A BSFC of $0.419 \mathrm{lb} / \mathrm{bhp}-\mathrm{hr}$ is very good, however, and competitive or better than that of existing production CNG engines. Work in Phase II showed that the modified engine, for a given $\mathrm{NO}_{\mathrm{x}}$ level, had a 10-percent increase in efficiency and a 30-percent decrease in $\mathrm{HC}$ emissions. The data obtained during this testing are in agreement with that finding. Figure 7 shows the $\mathrm{NO}_{\mathrm{x}}-\mathrm{BSFC}$ tradeoff over the FTP cycle for the test engine (represented in triangle symbols for the lowest $\mathrm{NO}_{\mathrm{x}}$ and average cycles). The figure also shows a region typical of current production gas engines. This region was defined by actual FTP cycle results from production gas engines, and SwRI believes this accurately reflects the current state of the art. As can be seen from the data, the engine developed by SwRI for this project is significantly superior to the current state of the art in production gas engines, in terms of the $\mathrm{NO}_{x}-\mathrm{BSFC}$ tradeoff over the FTP cycle.

Table 5 was prepared to compare the emission levels obtained to the formal project goal of achieving the CARB Ultra-Low Emissions Vehicle (ULEV) standards. 


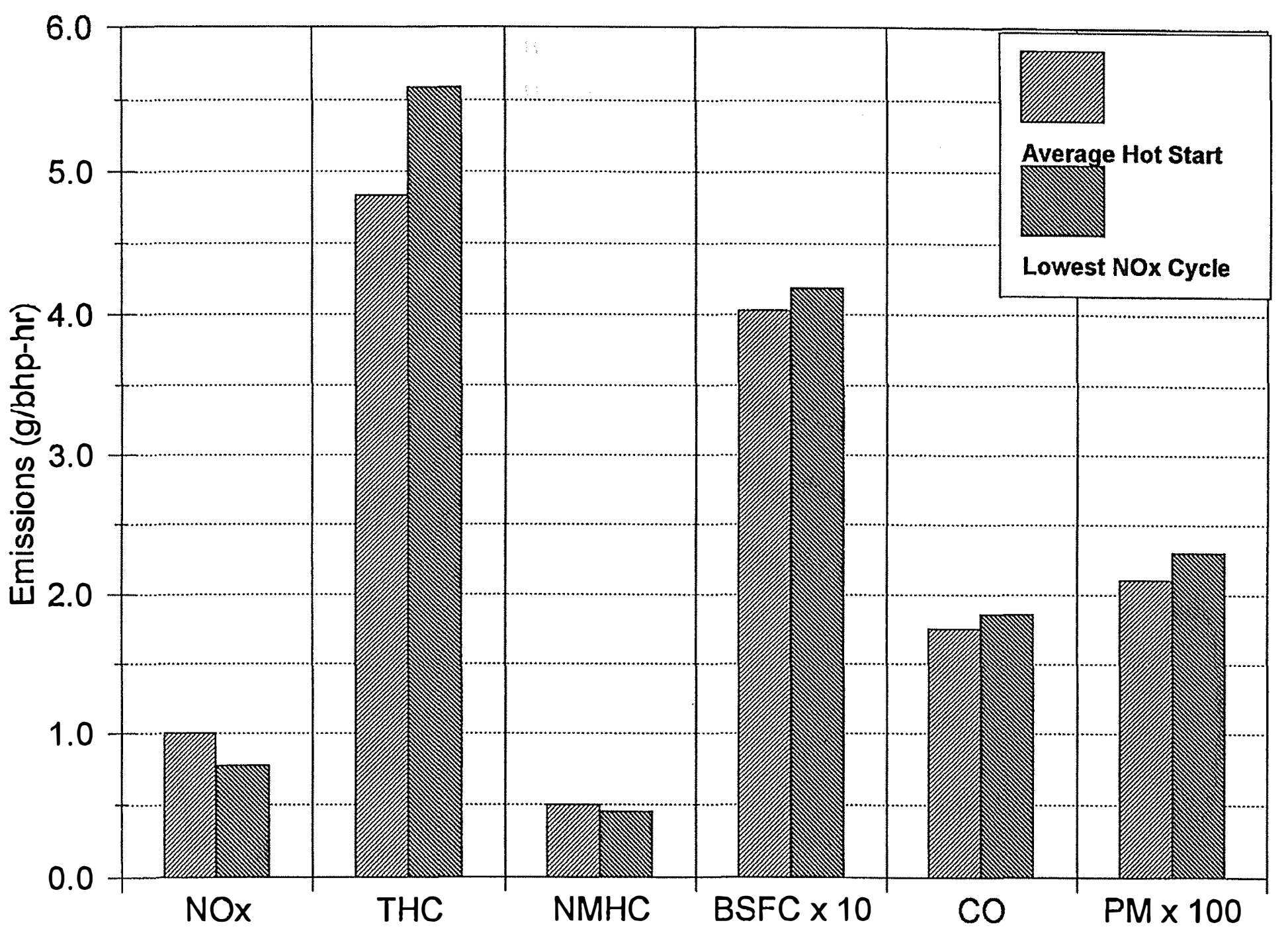

Figure 6. FTP transient-test cycle result 


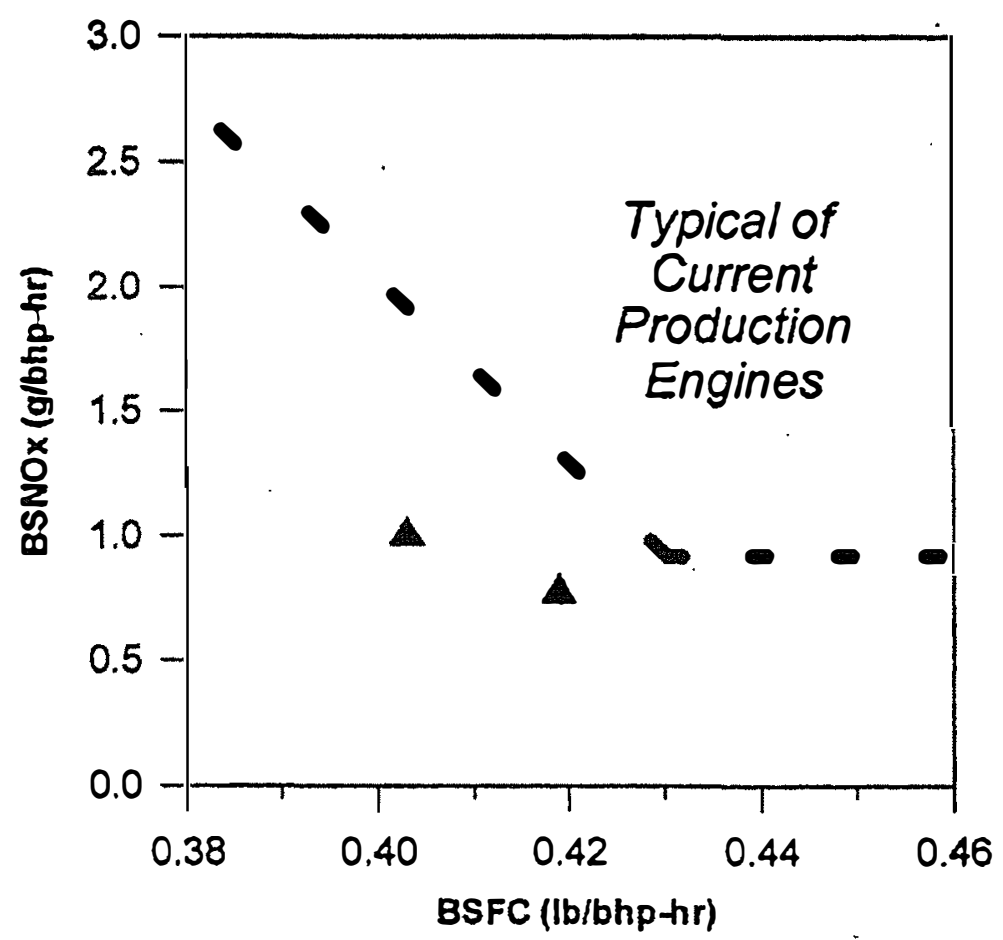

Figure 7. A comparison of FTP transient-test cycle $\mathrm{NO}_{x}$ emissions versus BSFC

Table 5. Emissions level comparison (units-g/bhp-hr)

\begin{tabular}{||l|c|c|c|c||}
\hline \multicolumn{1}{|c|}{ Pollutant } & $\begin{array}{c}\text { Cold-Hot } \\
\text { Composite }\end{array}$ & $\begin{array}{c}\text { Average } \\
\text { Hot Start }\end{array}$ & $\begin{array}{c}\text { Low } \\
\text { NO }_{\mathbf{x}}\end{array}$ & ULEV \\
\hline \hline $\mathrm{NO}_{\mathrm{x}}+\mathrm{NMHC}$ & 1.429 & 1.494 & 1.218 & 2.5 \\
\hline \hline $\mathrm{CO}$ & 1.768 & 1.751 & 1.857 & 7.2 \\
\hline \hline $\mathrm{PM}$ & $0.025^{*}$ & 0.021 & 0.023 & 0.050 \\
\hline \multicolumn{2}{|l|}{} \\
\hline \multicolumn{2}{|l|}{ Estimated - See Table 3 } \\
\hline
\end{tabular}

Note that the emissions levels from this engine on an average cycle are well below the ULEV standards, and the levels from the low $\mathrm{NO}_{x}$ cycle are less than one-half of the ULEV standards. The emissions levels shown are again engine-out emissions. The data from Table 5 are also displayed in Figure 8.

One additional requirement for the ULEV emissions standards is the level of formaldehyde (HCHO) emissions. The maximum allowable $\mathrm{HCHO}$ level is set at $0.025 \mathrm{~g} / \mathrm{bhp}-\mathrm{hr}$, much lower than any conventional, lean-burn, natural gas engine can attain without aftertreatment. Fortunately, oxidation catalysts are quite effective at reducing $\mathrm{HCHO}$ to reasonable levels, provided the catalyst conversion efficiency is high. 


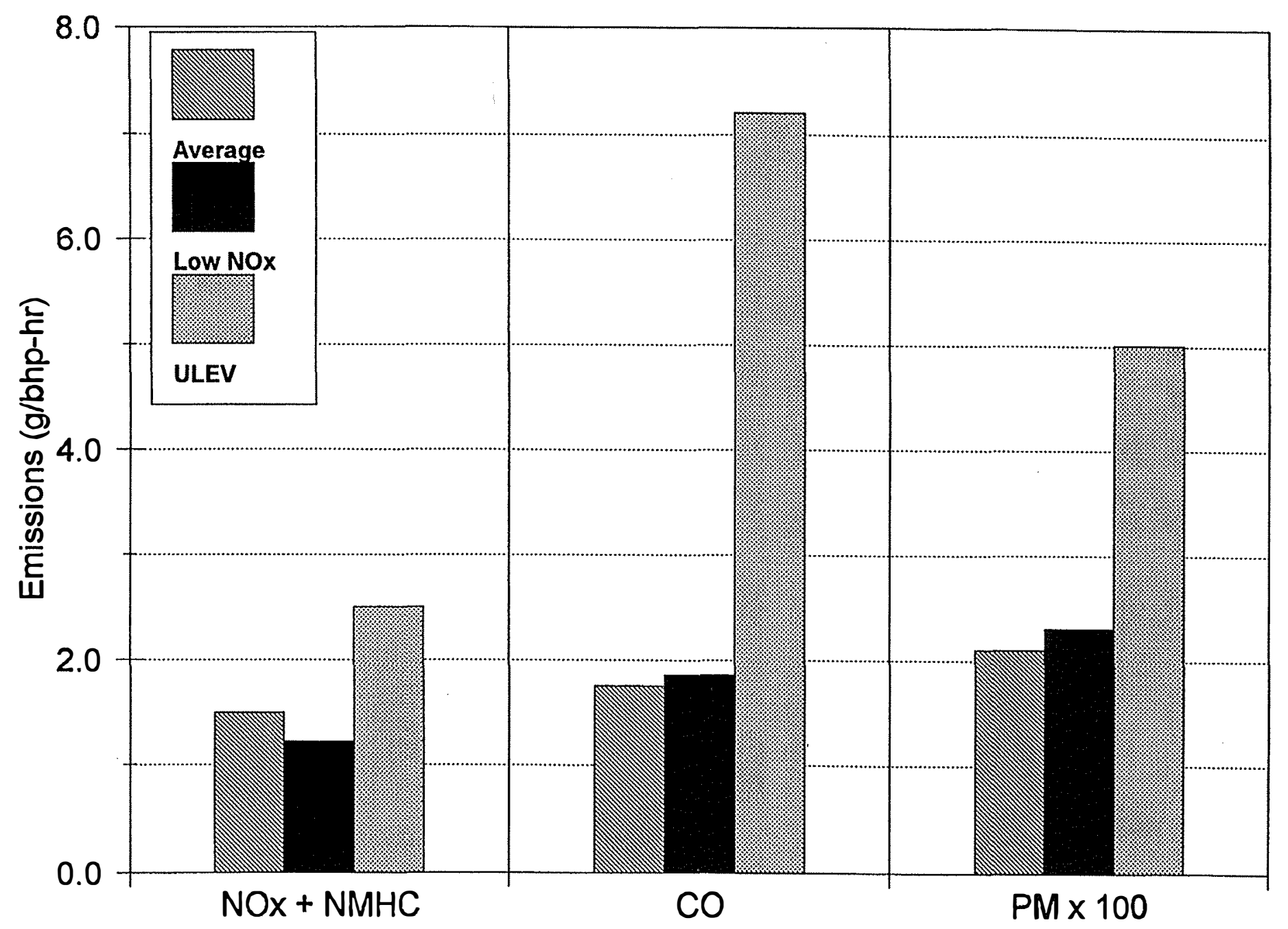

Figure 8. Comparison of FTP test cycle results with ULEV standards 
$\mathrm{HCHO}$ emissions were measured over several cycles using the standard wet-chemistry technique; this involves bubbling a proportional sample of dilute exhaust gas through chilled impingers filled with a solution of 2,4-dinitro phenylhydrazine and perchloric acid. This solution is then analyzed using high-pressure liquid chromatography. For a baseline case, $\mathrm{HCHO}$ was measured over the coldstart/hot-start sequence 5C-5H. To determine the $\mathrm{HCHO}$ conversion ability of the catalyst, $\mathrm{HCHO}$ emissions were also measured for the catalyst-equipped engine over test cycles 7C-7HB. The data for both sets of runs are shown for comparison in Table 6.

Table 6. Summary of $\mathrm{HCHO}$ emissions data

\begin{tabular}{||l|c|c|c||}
\hline Run & Cycle Type & Catalyst & $\begin{array}{c}\text { HCHO Emissions } \\
\text { (g/bhp-hr) }\end{array}$ \\
\hline \hline $5 \mathrm{C}$ & Cold & No & 0.221 \\
\hline \hline $5 \mathrm{H}$ & Hot & No & 0.200 \\
\hline \hline $5 \mathrm{C}-5 \mathrm{H}$ & Composite & No & 0.203 \\
\hline \hline $7 \mathrm{C}$ & Cold & Yes & 0.036 \\
\hline \hline $7 \mathrm{HB}$ & Hot & Yes & 0.033 \\
\hline 7C-7HB & Composite & Yes & 0.034 \\
\hline \hline
\end{tabular}

Engine-out HCHO emissions over the composite cold-start/hot-start cycle (5C-5H) were approximately $0.203 \mathrm{~g} / \mathrm{bhp}-\mathrm{hr}$. As expected, this level was eight times higher than the CARB ULEV standard of $0.025 \mathrm{~g} / \mathrm{bhp}-\mathrm{hr}$. When the engine was equipped with an oxidation catalyst during tests 7C-7HB, the composite $\mathrm{HCHO}$ emissions were reduced significantly to approximately $0.033 \mathrm{~g} / \mathrm{bhp}-$ $\mathrm{hr}$, or roughly 34 percent above the goal. This amounted to a conversion efficiency of about 83 percent, slightly short of the 88-percent conversion required to meet the ULEV level.

SwRI had expected, however, that the HCHO emissions would be reduced to well below the ULEV levels based on previous experience with these types of catalysts. An inquiry to the muffler manufacturer revealed that the catalyst loading for this particular catalyst/muffler combination used by John Deere and Blue Bird had been reduced compared to previous catalysts. This reduction in catalytic material reduced the overall conversion efficiency of the catalyst. The catalyst had been suspect earlier in the transient testing, since the amount of hydrocarbon conversion was also low, although the $\mathrm{CO}$ conversion efficiency remained high.

Due to time constraints in the transient-capable cell, no additional work was done to reduce the formaldehyde emissions further. A catalyst was ordered from Miratech, an industrial catalyst firm. Plans were made to evaluate this catalyst during the chassis dynamometer test program. More discussion about the effectiveness of this catalyst is included in the section describing the second set of transient chassis dynamometer tests. 


\subsubsection{Diagnostics Verification}

As mentioned previously, during most of the transient testing program, the diagnostics systems were disabled in order to prevent any anomalous system behavior from affecting the results of the tests. The diagnostic systems were verified, however, through several transient and steady-state tests. These tests are detailed in the following sections.

\subsubsection{Humidity Compensation}

The humidity compensation system was developed to allow modification of engine operational parameters, such as fuel/air equivalence ratio, spark timing, and boost pressure to compensate for humidity effects on the combustion process near the lean limit. The humidity compensation system also compensated for humidity effects on the UEGO sensor itself. A detailed explanation of the purpose and specific design of the humidity compensation system developed for the project is contained in the Phase II project report as well as SAE paper No. 971706.

During most of the testing, the humidity compensation system was disabled because the tests are run at a standard humidity level. The system was disabled by setting all of the compensation table values to zero. To test the system, the table was filled in with values developed during Phase $\Pi$ testing. The test cell intake air-conditioning system was shut off, allowing the dew point of the air to rise from approximately $57^{\circ}-58^{\circ} \mathrm{F}$ to $68^{\circ}-69^{\circ} \mathrm{F}$, an approximate 60 -percent increase in specific humidity. During a trial transient cycle, the humidity compensation system enrichened the fuel/air mixture, advanced the spark timing, and increased the boost pressure as compensation for the change in humidity. The average dilute $\mathrm{NO}_{\mathrm{x}}$ concentration over the cycle increased by approximately six percent, and the average dilute $\mathrm{HC}$ concentration increased by only five percent. Attempts to run the engine at these humidity levels without humidity compensation yielded much higher hydrocarbon emissions and poor performance, including some misfires. This proved that the humidity compensation system worked successfully in maintaining performance.

A test for record, run $4 \mathrm{HD}$, was conducted to document the results obtained using the humidity compensation system. During the test, the humidity sensor drifted slightly high, and the engine calibration was overcompensated. Due to the nonlinear increase in the desired equivalence ratio with increasing humidity, the engine was overly enriched. This additional enrichment led to a much higher $\mathrm{NO}_{\mathrm{x}}$ level of $1.47 \mathrm{~g} / \mathrm{bhp}-\mathrm{hr}$ and lower $\mathrm{HC}$ emissions, with no evidence of misfire. This $\mathrm{NO}_{x}$ number is a corrected value based on the increased humidity level of the intake air, but the actual $\mathrm{NO}_{x}$ level from the engine, to which the environment would actually be exposed, was approximately $1.33 \mathrm{~g} / \mathrm{bhp}$-hr. The emissions results are evidence that the humidity compensation system was working and effectively overcompensated for the humidity change. Without the humidity compensation system, HC emissions would have risen sharply from the baseline, with possible misfire and engine performance problems occurring. $\mathrm{NO}_{x}$ emissions would likely have been slightly reduced from the baseline.

In practical terms, the humidity compensation system functioned correctly; it prevented the occurrence of misfire and affected the emissions output of the engine only slightly. Also, note that a humidity sensor with faster response times and more stable output would eliminate the overcompensation issue. Also, the rapid change in humidity that occurred as conditioned air was first introduced at the beginning of the transient test was an unrealistically large and abrupt transient when compared to the relatively slow humidity transients that would occur in actual operation. 
Although the relative humidity sensor used for the project was not designed for engine and vehicle use, the humidity compensation system as a whole is a suitable candidate for production.

\subsubsection{Knock and Misfire Detection}

To check the effect of the knock and misfire detection systems, their respective compensation systems were enabled, and a transient test was run.

\subsection{Knock Detection}

Single knock pulses were noted infrequently during the transient test. Knock was not expected during the cycles due to the lean operating conditions and the use of retarded spark timings. These knock signals were most likely triggered by noise, although it is possible that random knocking cycles were present during the tests.

To verify that the knock sensing and detection system was working correctly, a steady-state test was conducted. In order to protect the engine, "knocking" was induced by tapping the cylinder head in the vicinity of the knock sensor. The response of the system was recorded using the datalogging feature of the GEM controller. Both the knock signals and the spark timing multiplier term were recorded. The multiplier term effectively retards the spark timing as a function of the frequency and severity (as measured by duration) of the knock signals. Figure 9 is a plot of the data recorded during this test. Due to the relatively low sampling rate used by the datalogger, not all of the shortduration knock pulses were recorded, but their effect on the engine controller can be seen.

Transient testing of the knock detection and control system revealed no major deficiencies in system performance. However, occasional minor mis-triggering of the knock detection system was noted. The knock detection and control system developed during the project is not viewed as a candidate for direct incorporation into a production engine. However, a similar system, possibly utilizing an alternative knock sensor type, could be used in the future.

\subsection{Misfire Detection}

Also during the transient test, many false triggers were noted on the misfire detection system. The triggers were determined to be false by simultaneously comparing the occurrence of the trigger signals and the level of $\mathrm{HC}$ emissions. Since the $\mathrm{HC}$ emissions usually remained quite low during the triggering period, SwRI concluded that no misfire was occurring. Based on these signals, the misfire detection threshold was adjusted until the number of false triggers was minimized.

Under steady-state conditions, the misfire system was tested by disabling the ignition coil on one cylinder using the ignition diagnostic system built into the GEM controller. The results of this test are shown in Figure 10. This plot shows the misfire trigger signals and their effect on the misfire compensation term which modified the equivalence ratio. This multiplier enriches the fuel/air mixture as a function of the frequency of misfires. Again, due to sampling-time constraints, some of the misfire trigger pulses were not recorded, but their effects can be seen.

Due to the results from the misfire detection system over the transient tests and the nature of the misfire detection system itself, it was not felt that the misfire detection system used on the project was a good candidate for production. However, through applying this system on the engine, the development of a suitable misfire detection system for production could be more easily accomplished. 


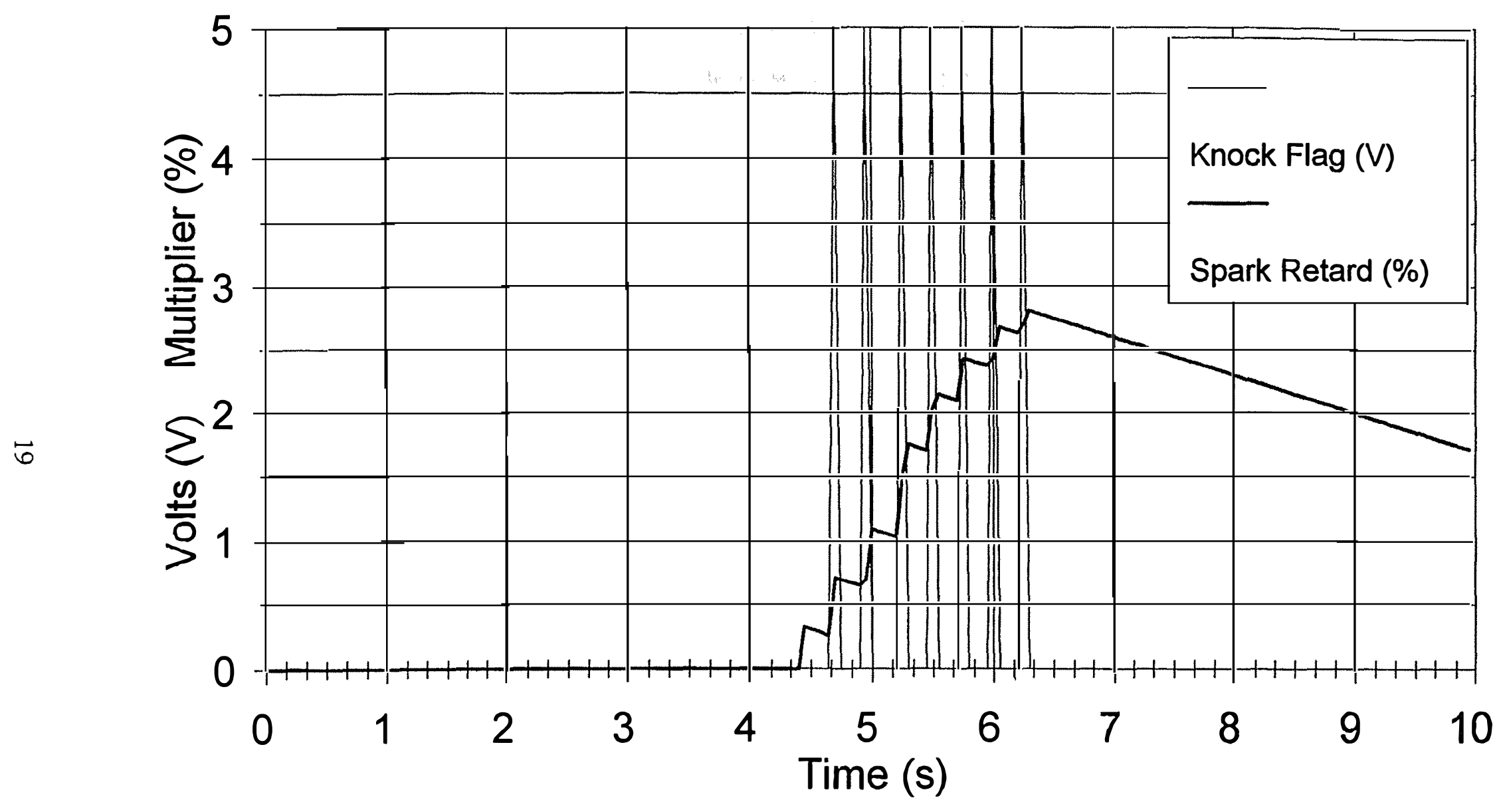

Figure 9. Results from knock control system test 


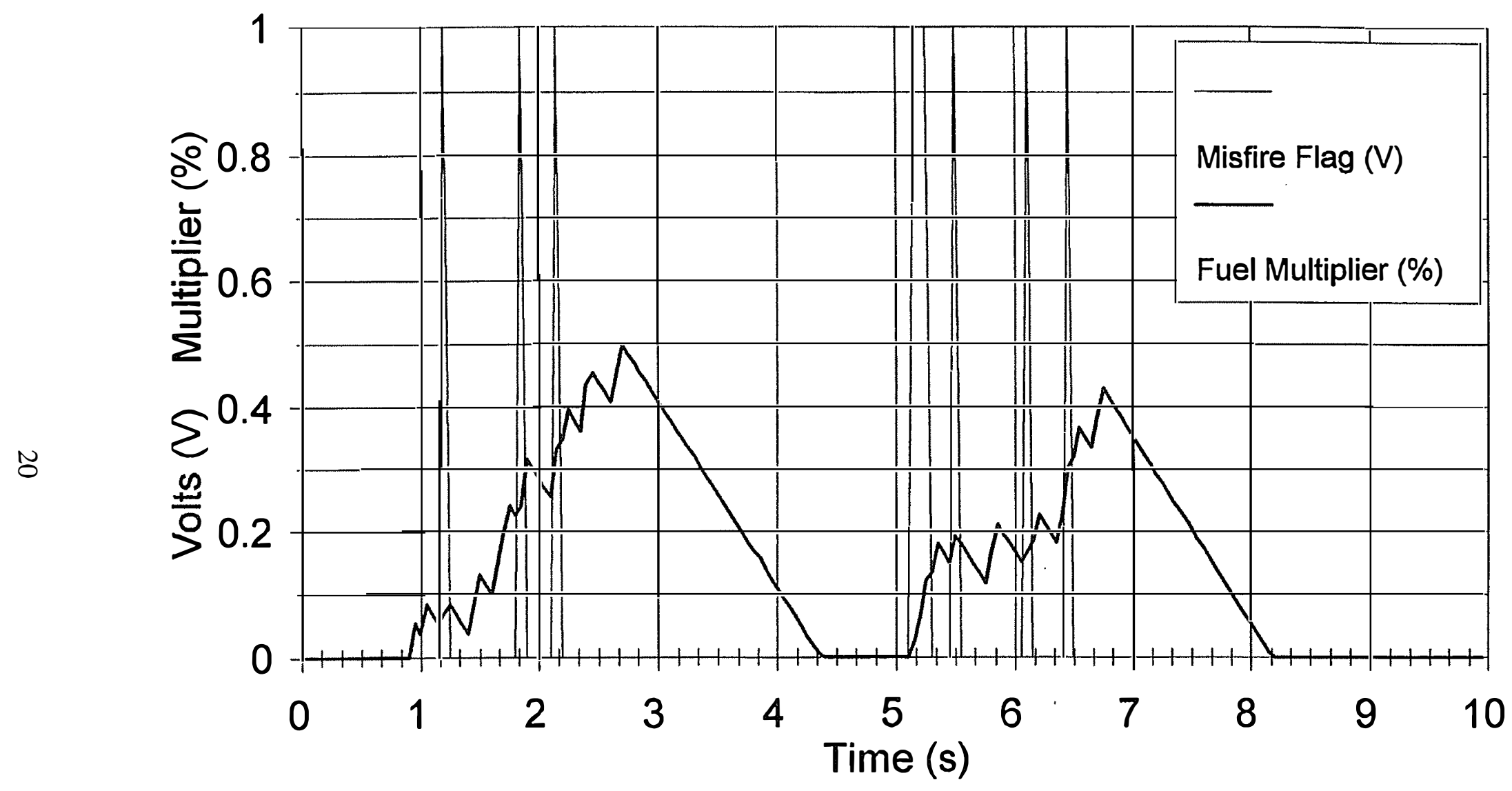

Figure 10. Results from misfire control system test 


\subsubsection{Surge Suppression}

The surge suppression system was enabled throughout nearly all of the transient tests. Details of the surge suppression system are contained in the final report for Phase $\Pi$ of the project. In general, the surge suppression system involved the actuation of a recirculation valve located in the turbocharger compressor housing. Recirculation valve actuation was accomplished via a three-way solenoid valve which was driven by the engine control system. The three-way valve applied turbocharger boost air onto the recirculation valve when the valve was to be closed and applied vacuum to the valve for radid opening. The vacuum was supplied via a vacuum resevoir, charged by the intake manifold. The amount of surge detected audibly during the entire test sequence was very minimal and present only during the most severe transients. The system proved itself to be practical and repeatable and is a good candidate for application to a production engine.

In order to illustrate the performance of this system, two load step-down tests were conducted. These tests were run at $1800 \mathrm{rpm}$ at a high load so that the boost pressure was high. The throttle was then closed quickly, thereby inducing surge in the turbocharger compressor. In the first test, the surge suppression system was disabled. During the load step-down, the characteristic surging sound was heard easily. Figure 11 shows the effect of the rapid throttle closure on the pre-throttle pressure, which is the pressure seen by the compressor wheel. Note the large spike in pressure and subsequent pressure oscillations typical of compressor surge. A second test was run with the surge suppression system enabled. The results of the second test are included in Figure 12. No surge was audible, and the figure shows that the harmful pressure oscillations were eliminated.

\subsubsection{Final Steady-State Engine Performance}

Subsequent to the transient emissions tests on the laboratory engine, the engine was re-installed in the steady-state test cell and mapped to document the engine performance with the final engine calibration. For the final steady-state mapping tests, the engine was operated over a full range of points throughout the engine operating range, with no engine control system calibration modifications (i.e., the $1.0 \mathrm{~g} / \mathrm{bhp}-\mathrm{hr} \mathrm{NO}_{\mathrm{x}}$ calibration was used). Relevant engine parameters and raw gaseous emissions were measured. Full-load engine performance data including engine speed, torque, horsepower, brake mean effective pressure (BMEP), brake thermal efficiency (BTE), and pre-turbine exhaust temperatures have been included in Table 7 to show final steady-state engine performance.

Table 7. Full-load engine performance-final engine calibration

\begin{tabular}{||c|c|c|c|c|c||}
\hline $\begin{array}{c}\text { Engine Speed } \\
(\text { RPM })\end{array}$ & $\begin{array}{c}\text { Engine Torque } \\
(\mathbf{l b - f t})\end{array}$ & $\begin{array}{c}\text { Engine Power } \\
(\mathbf{b h p})\end{array}$ & $\begin{array}{c}\text { BMEP } \\
(\mathbf{p s i})\end{array}$ & $\begin{array}{c}\text { BTE } \\
(\%)\end{array}$ & $\begin{array}{c}\text { Pre-Turbine } \\
\text { Temperature } \\
(\mathbf{D e g} \text { F) }\end{array}$ \\
\hline \hline 2200 & 628 & 262 & 192 & 35.9 & 1284 \\
\hline 2000 & 688 & 262 & 210 & 37.3 & 1261 \\
\hline 1800 & 747 & 255 & 228 & 38.5 & 1244 \\
\hline 1600 & 782 & 238 & 239 & 38.2 & 1236 \\
\hline 1400 & 811 & 216 & 248 & 38.4 & 1220 \\
\hline \hline
\end{tabular}




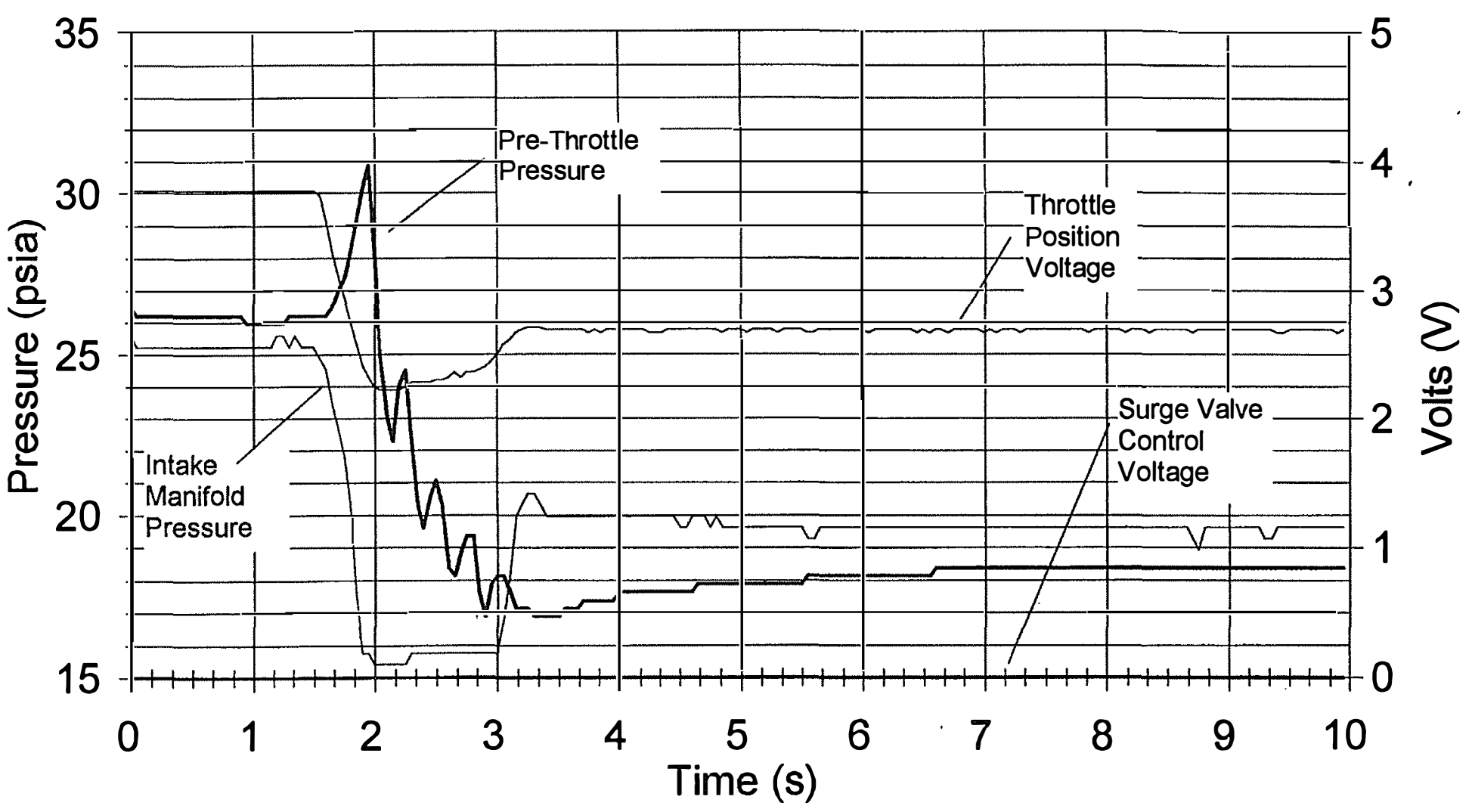

Figure 11. Results for surge suppression system with system disabled 


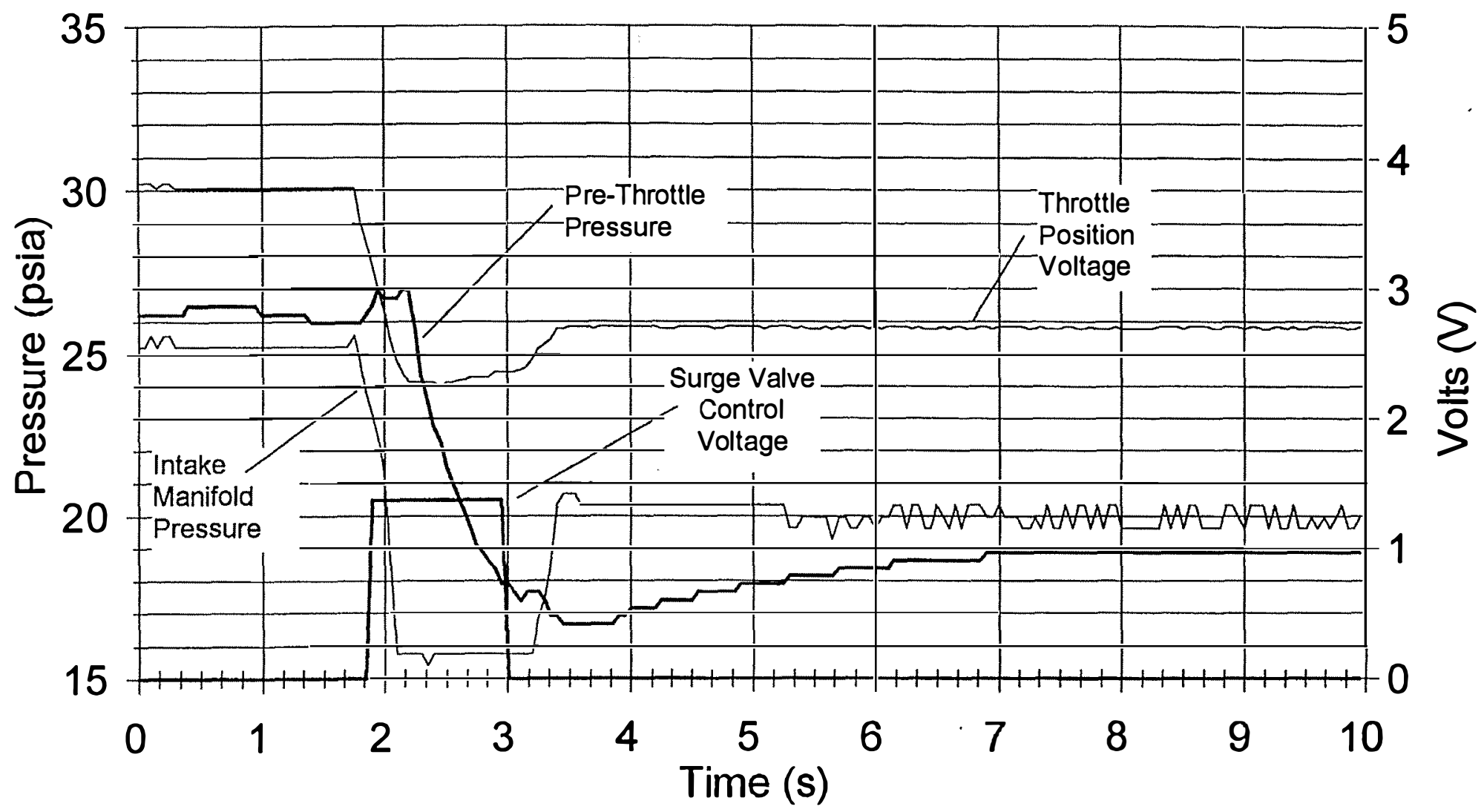

Figure 12. Results for surge suppression system with system enabled 


\subsection{Phase IV-Demonstration}

\subsection{Engine/Vehicle Integration}

The production-type engine originally mounted in the bus was modified to fully reflect all of the changes that had been adopted during Phases $\Pi$ and $I I I$, essentially making this engine a duplicate of the dynamometer development engine. Engine components that were replaced or modified included the following: pistons, liners, valves, valve seats, valve guide seals, exhaust manifold, and turbocharger. The surge suppression valve was added along with its required plumbing, and the surge-suppression vacuum tank was mounted. The pre-turbine pressure and exhaust back-pressure sensors were removed, and a pre-throttle pressure sensor was added. A magnetic pickup that sensed flywheel teeth was mounted for the misfire detection system, and the knock and humidity sensors were added. Additional wiring harnesses were installed for all of the new control hardware, and provisions were also made for mounting the auxiliary ECM. In addition, the bus was equipped with the latest versions of the main engine ECM and Flotech electronic throttle body. The modified engine is shown in Figure 13, a photograph of the engine compartment on the bus. The bus was also equipped with a combination catalyst/muffler identical to that used during some of the transient engine testing.

\subsubsection{Initial Chassis Dynamometer Tests}

\subsubsection{Preparation}

The auxiliary ECM used on the dynamometer test engine was mounted on the bus and connected to the modified wiring harness. Figure 14 is a close-up photograph of the ECM installation that shows how the dual ECM package was installed. Calibration data for a $1 \mathrm{~g} / \mathrm{bhp}-\mathrm{hr} \mathrm{NO}_{\mathrm{x}}$ level, as developed during the FTP transient testing, were programmed into the main ECM controller EPROM chip, and this chip was installed in the main ECM. A similar chip containing calibration data for a $0.77 \mathrm{~g} / \mathrm{bhp}-$ $\mathrm{hr} \mathrm{NO}_{\mathrm{x}}$ level was also prepared and kept for future work.

Driving tests confirmed that the engine was performing well. Additional testing was conducted to ensure that the engine was operating at the correct fuel/air equivalence ratio, so that the emissions levels from the engine would be correct and so that misfire would not occur. The emissions cart was used to measure the exhaust equivalence ratio, by installing a sampling probe that extended up into the exhaust pipe. In addition, the exhaust back-pressure sensor was left intact, and this sensor was monitored during operation of the bus. The bus engine was tested at idle and high load through stall tests to determine if the UEGO calibration and back-pressure compensation were correct. The estimated back-pressure on the engine appeared to match the estimated value calculated by the main engine ECM, and only small changes were required in the UEGO of fset table. Compensation for these effects was introduced through the UEGO offset table of the humidity compensation function in the auxiliary ECM.

Following these preparations, the bus was taken to the SwRI chassis dynamometer emissions test facility. Figure 15 is a photograph of the bus as installed on the chassis dynamometer. For all of the 


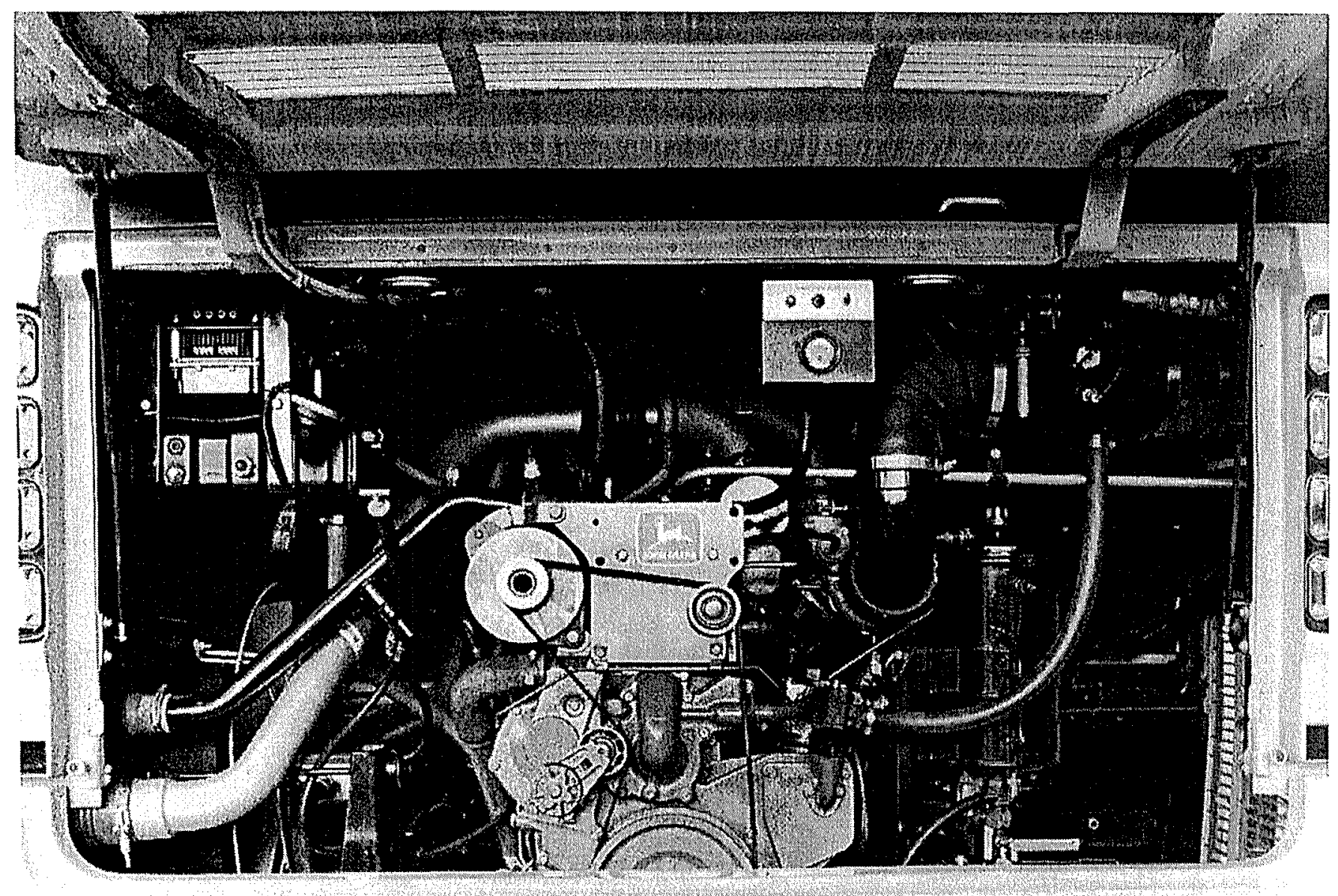

Figure 13. Modified test engine as installed in Envirobus 2000 


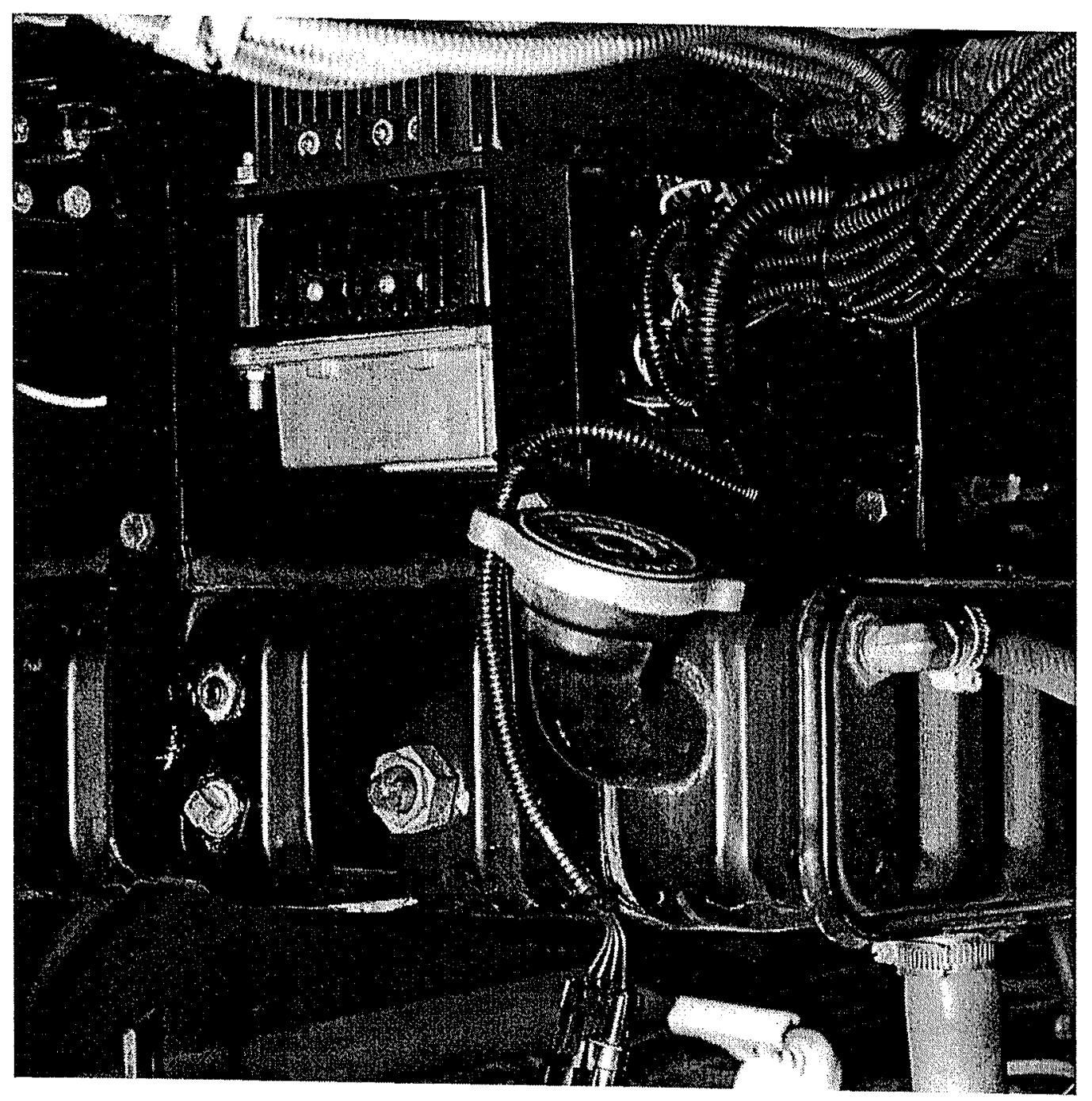

Figure 14. Close-up view of ECM installation 


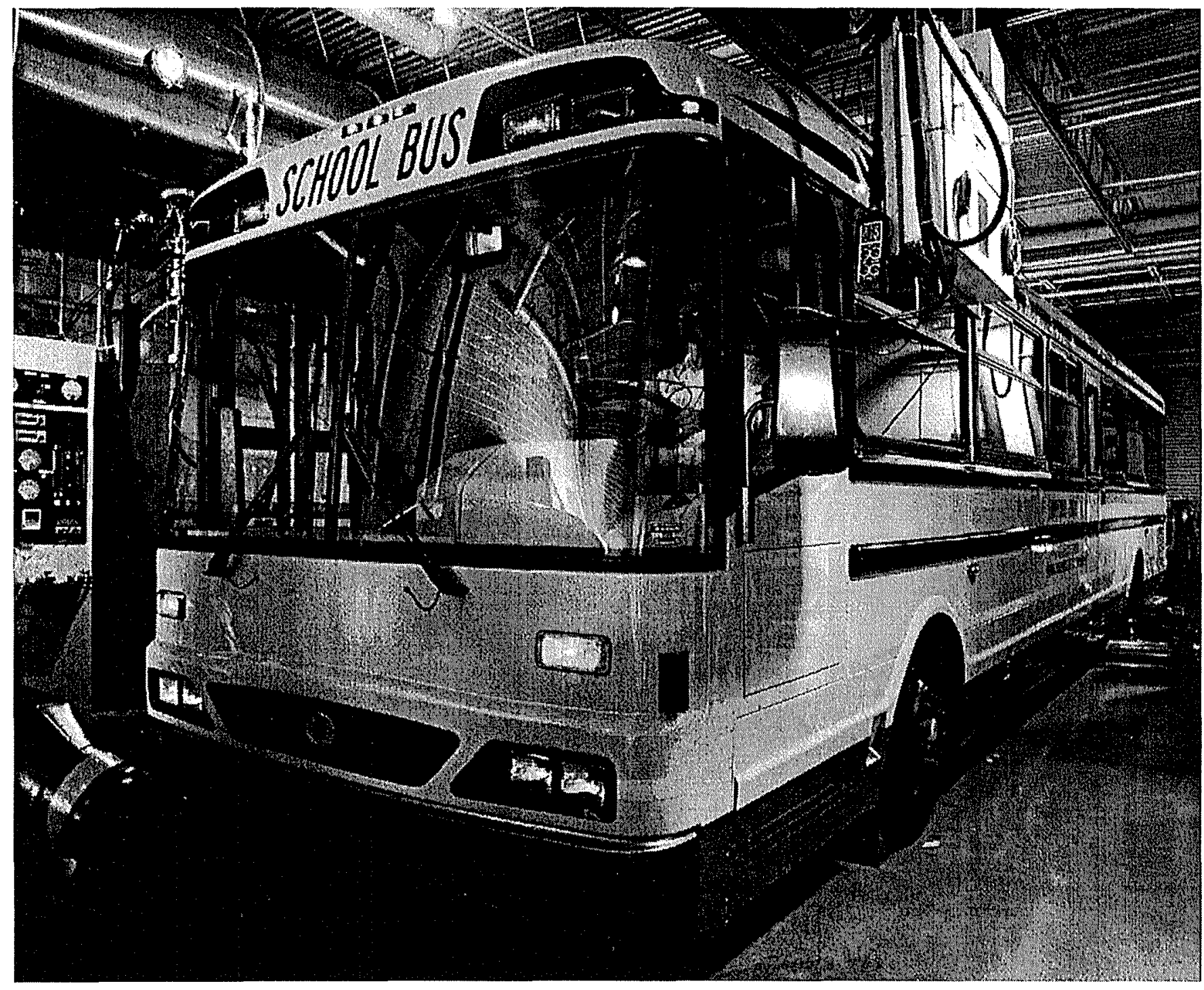

Figure 15. Envirobus 2000 under test at chassis dynamometer facility 
testing, $\mathrm{NO}_{\mathrm{x}}, \mathrm{NMHC}$, and $\mathrm{CO}$ were measured. $\mathrm{HCHO}$ emissions were measured for some of the tests; however, particulate emissions were not measured. The vehicle weight for the chassis tests was approximately 23,000 pounds.

\subsubsection{Test Sequence}

The bus was tested overtwo different cycles: the chassis version of the FTP heavy-duty chassis cycle (HDCC) and the central business district (CBD) driving cycle. Figure 16 shows the HDCC cycle as a function of engine speed and load as indicated by throttle position. This cycle attempts to simulate the operating characteristics of a heavy-duty vehicle, such as a truck, in urban and freeway conditions, and is based on the heavy-duty engine dynamometer test. Similarly, Figure 17 shows the characteristics of the CBD cycle. The CBD cycle simulates the operating conditions for a typical urban transit bus. The bus alternates between idle and approximately $20 \mathrm{mph}$, simulating the stopand-go operation of a transit bus, stopping to load and unload passengers at frequent intervals.

\subsubsection{Emissions Test Results}

Several problems were encountered early in the test program but were corrected quickly. For example, tire overheating was initially a problem, but additional cooling fans were used to lower the tire temperature to acceptable levels. A minor problem was also found with the main ECM calibration memory chip, but reprogramming the chip corrected the problem.

Two sets of runs were conducted following the initial shakedown. The first set used the $1.0 \mathrm{~g} / \mathrm{bhp}-\mathrm{hr}$ $\mathrm{NO}_{x}$ calibration and consisted of a cold-start/hot-start FTP test sequence followed by a CBD cycle. The second set was a hot-start FTP test followed by a CBD cycle, using the $0.77 \mathrm{~g} / \mathrm{bhp}-\mathrm{hr} \mathrm{NO}_{\mathrm{x}}$ calibration.

Table 8 summarizes the results of the five runs. The emissions levels are all shown in units of grams per mile. Note that all of the emissions are at very low levels, particularly for a vehicle of this size. Figure 18 provides a graphical comparison for all of the HDCC runs. Figure 19 is a similar comparison of the CBD cycle results. During these tests, the ambient conditions (temperature and humidity) were very near the standard levels, so that the $\mathrm{NO}_{\mathrm{x}}$ correction factor was approximately 1.0 for all the tests.

Table 8. Chassis dynamometer emissions test results

\begin{tabular}{|c|c|c|c|c|c|}
\hline $\begin{array}{l}\text { Cycle } \\
\text { Type }\end{array}$ & Calibration & $\begin{array}{c}\mathrm{NO}_{\mathbf{x}} \\
(\mathrm{g} / \mathrm{mi}) \\
\end{array}$ & $\begin{array}{c}\text { NMHC } \\
(\mathrm{g} / \mathrm{mi})\end{array}$ & $\begin{array}{c}\mathrm{CO} \\
(\mathrm{g} / \mathrm{mi})\end{array}$ & $\begin{array}{r}\mathrm{HCHO} \\
(\mathrm{g} / \mathrm{mi})\end{array}$ \\
\hline HDCC (cold) & $\mathrm{NO}_{\mathrm{x}}=1.00 \mathrm{~g} / \mathrm{bhp}-\mathrm{hr}$ & 3.69 & 1.144 & 0.50 & 0.087 \\
\hline HDCC (hot) & $\mathrm{NO}_{\mathrm{x}}=1.00 \mathrm{~g} / \mathrm{bhp}-\mathrm{hr}$ & 2.86 & 1.125 & 0.39 & 0.085 \\
\hline CBD (hot) & $\mathrm{NO}_{\mathrm{x}}=1.00 \mathrm{~g} / \mathrm{bhp}-\mathrm{hr}$ & 3.05 & 1.068 & 0.33 & $\mathrm{n} / \mathrm{a}$ \\
\hline HDCC (hot) & $\mathrm{NO}_{\mathrm{x}}=0.77 \mathrm{~g} / \mathrm{bhp}-\mathrm{hr}$ & 2.68 & 0.911 & 0.37 & $\mathrm{n} / \mathrm{a}$ \\
\hline CBD (hot) & $\mathrm{NO}_{\mathrm{x}}=0.77 \mathrm{~g} / \mathrm{bhp}-\mathrm{hr}$ & 2.85 & 1.109 & 0.35 & $\mathrm{n} / \mathrm{a}$ \\
\hline
\end{tabular}




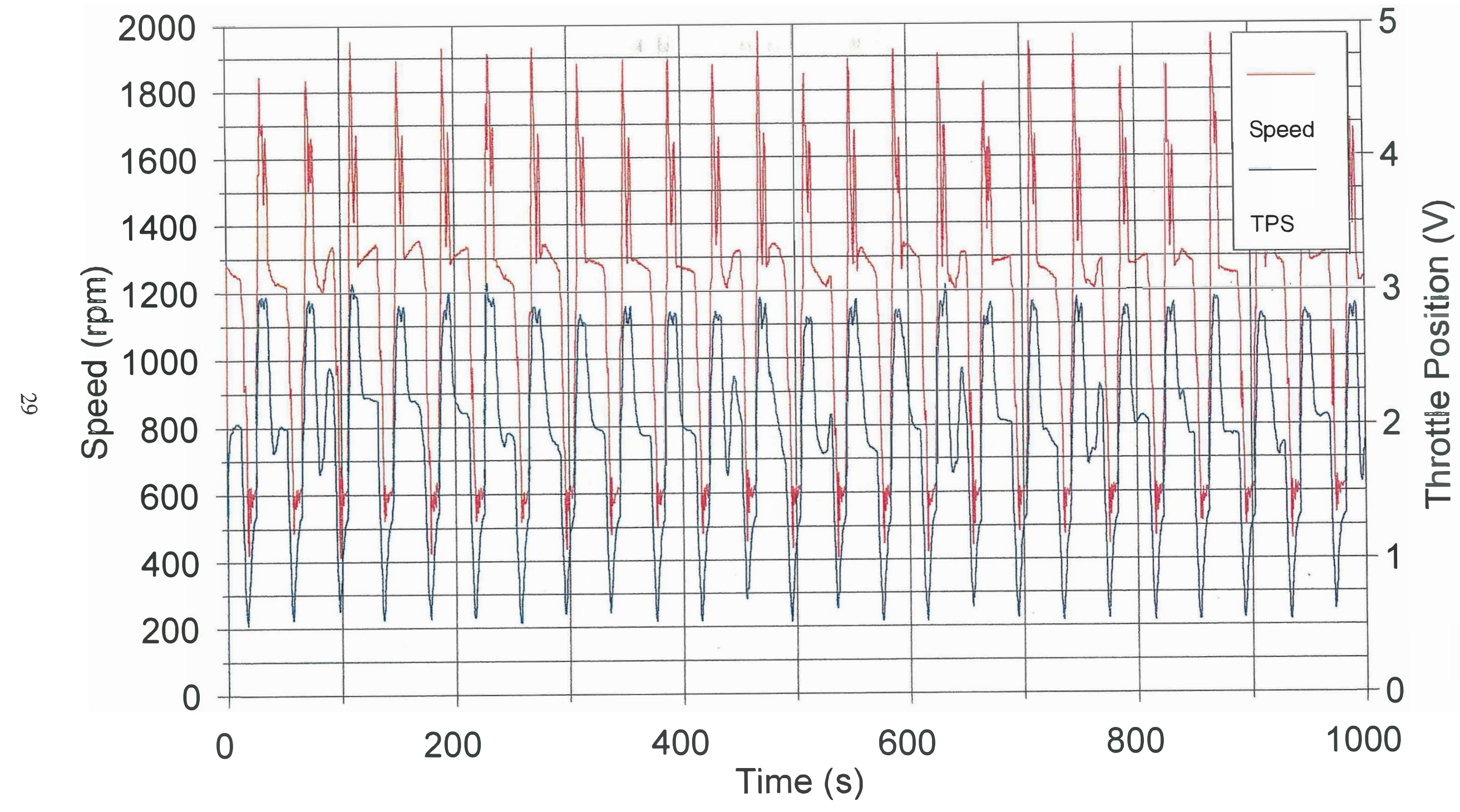

Figure 16. Plot of engine speed and throttle position for heavy-duty chassis cycle 


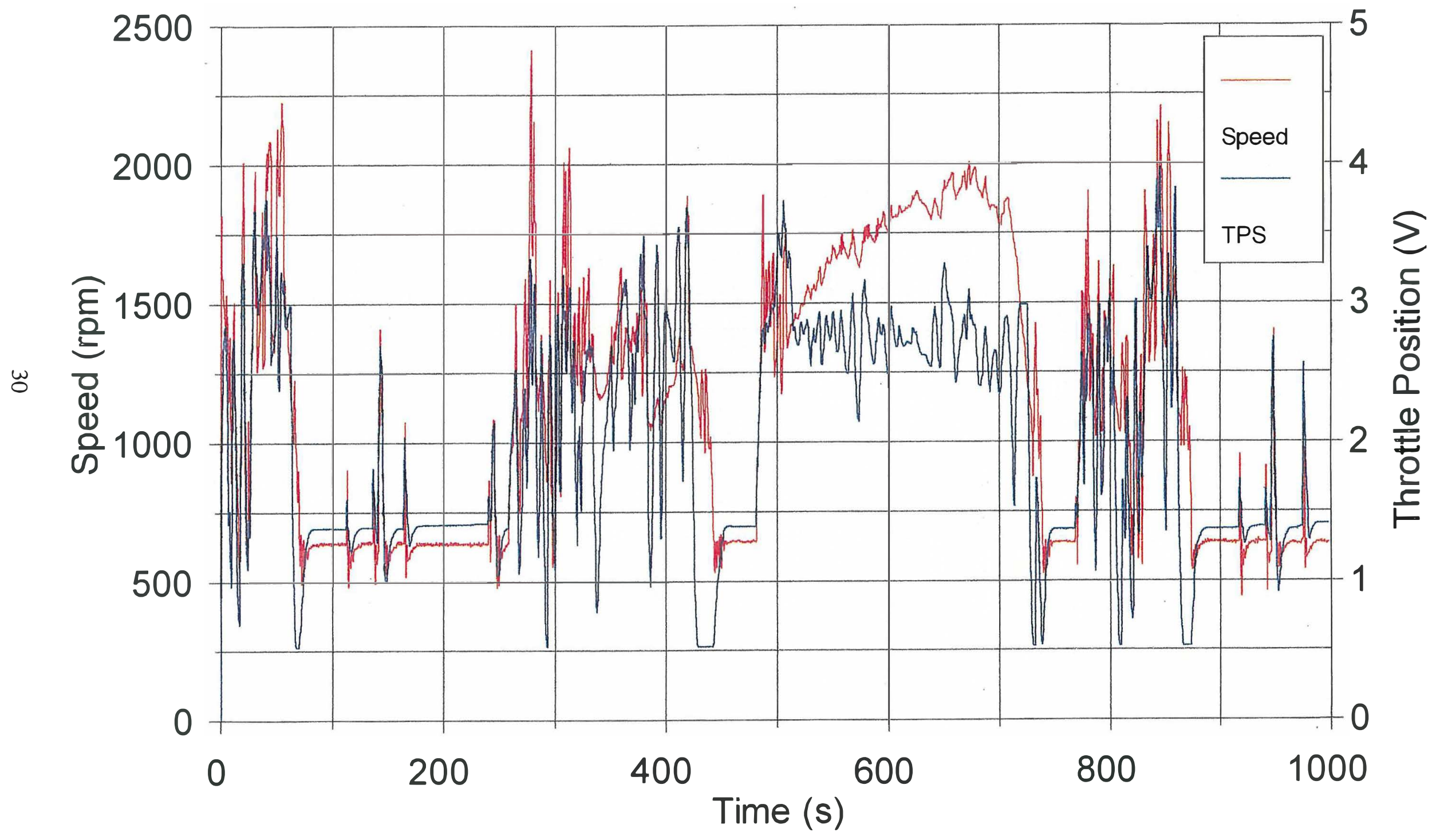

Figure 17. Plot of engine speed and throttle position for central business district cycle 


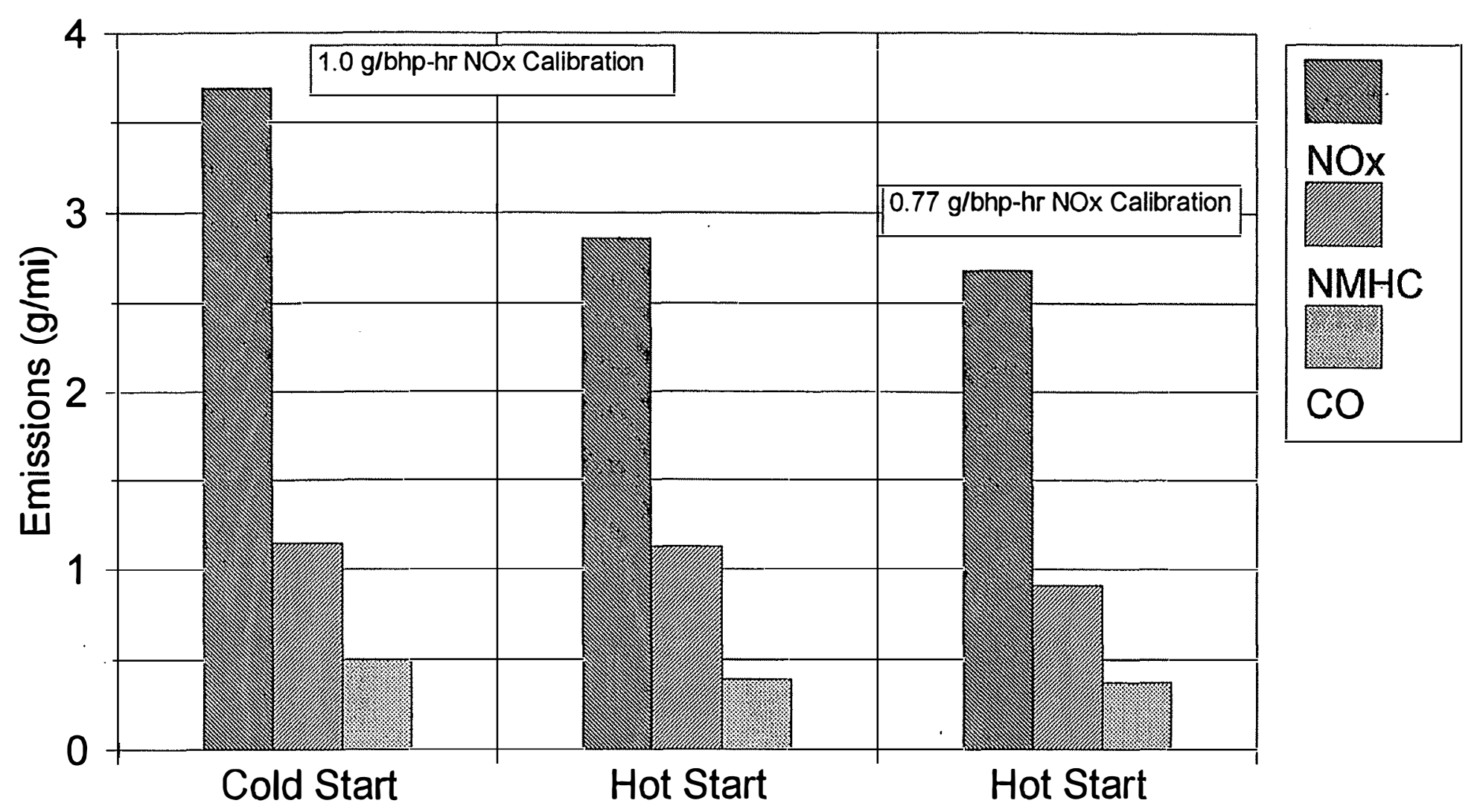

Figure 18. Comparison of emissions results for heavy-duty chassis cycle tests 


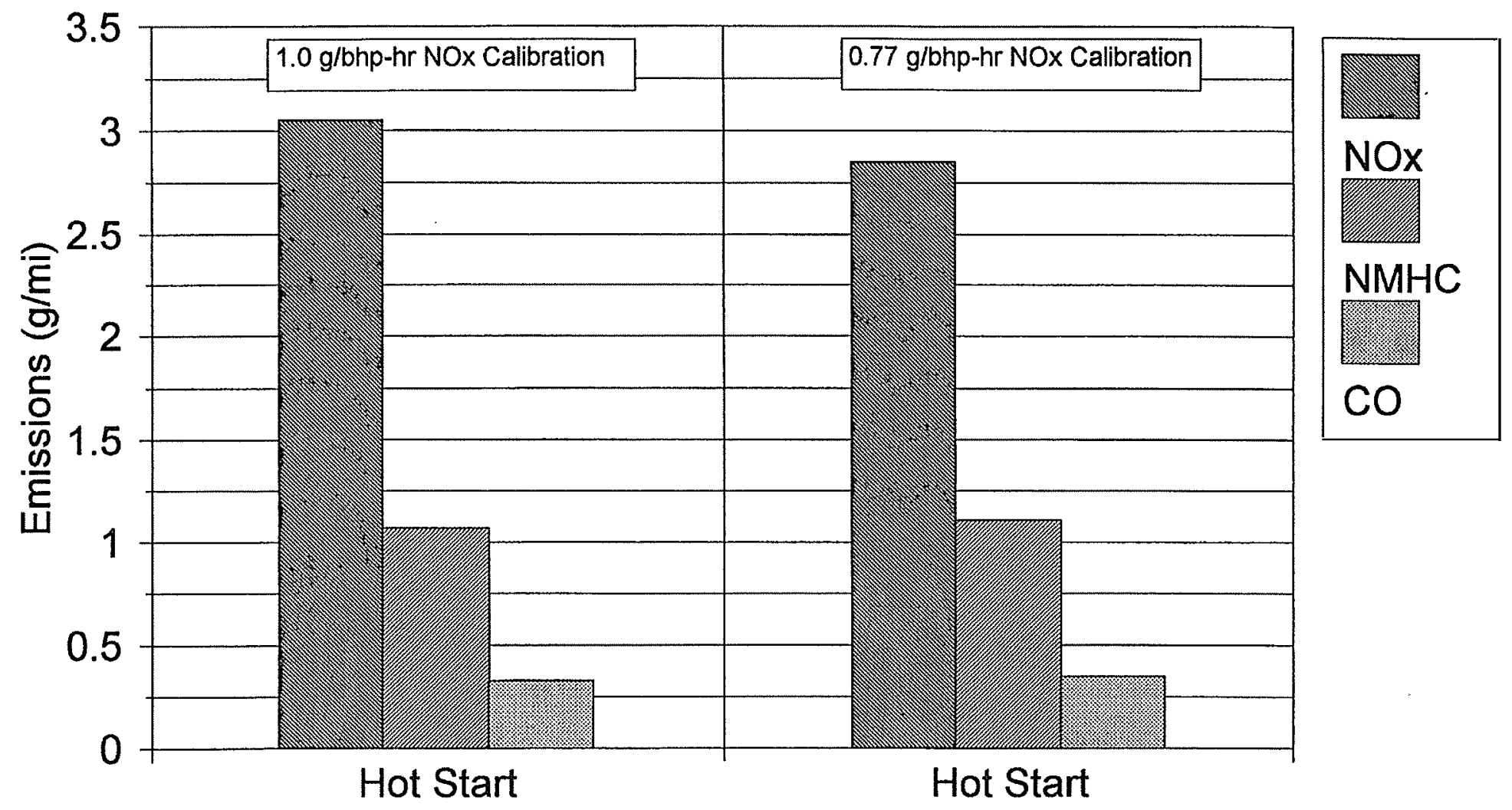

Figure 19. Comparison of emissions results for central business district tests 
As can be seen from the data in Table 8 , the lowest $\mathrm{NO}_{\mathrm{x}}$ engine calibration (i.e., $\mathrm{NO}_{\mathrm{x}}=0.77 \mathrm{~g} / \mathrm{bhp}$-hr) also produced the lowest $\mathrm{NO}_{x}$ emissions over the chassis dynamometer test cycles. However, the magnitude of the $\mathrm{NO}_{\mathrm{x}}$ emissions reduction (i.e., $1.0 \mathrm{~g} / \mathrm{bhp}-\mathrm{hr}$ calibration versus $0.77 \mathrm{~g} / \mathrm{bhp}$-hr calibration), for a given chassis dynamometer test cycle, is somewhat less than that shown over the FTP cycle. SwRI believes this can be attributed to several factors. First, the two chassis dynamometer cycles operate the engine over different conditions than the FTP cycle. This is particularly true of the CBD cycle. Secondly, the engine itself and engine control sensors were different between the FTP test engine and vehicle engine. It is possible that small differences in the engine and engine control system components could also contribute to this trend in emissions results (i.e., with a smaller emissions change on the second engine). These are issues that would need to be addressed in developing a production engine at these ultra-low emissions levels.

\subsubsection{Road Test}

\subsubsection{Initial Preparations}

Insurance coverage, license, and registration were obtained for the bus before starting the road test. In addition, the bus was inspected at a commercial vehicle inspection station, and a Texas state inspection sticker was obtained. The bus was transferred to the Automotive Fleet Laboratory for the required demonstration test. The Fleet Laboratory provided professional drivers to operate the bus on a 24-hours-per-day, 7-days-per-week schedule. This allowed the mileage accumulation to be obtained in a short amount of time; in some cases, over 700 miles per day were accumulated.

The road test route was identical to that used in the past by SwRI to test the reliability of natural gasfueled school buses. This route included both city and highwaydriving, with several periods of stopand-go operation. The route was originally based on observation of actual San Antonio school buses in operation. Figure 20 is a map which shows the route taken by the buses and the areas of stop-andgo and highway driving.

The bus was refueled at a CNG refueling station on the SwRI grounds. This station, shown in Figure 21, is typical of CNG refueling stations. The compressor can provide up to 3600 psi fill pressure, but usually the bus was refueled to a 3000 psi level. Refueling generally required approximately 10 minutes to complete.

To determine fuel economy, records of mileage and "gallons" of CNG used were kept. Before starting the test, the CNG dispenser was calibrated using a composite high-pressure tank and an electronic scale. This calibration showed the dispenser to be within 0.5 percent of the factory calibration. Also, at the beginning and end of the test, the bus fuel tanks were filled to $3000 \mathrm{psi}$ on a slow-fill basis to ensure complete filling. Fuel economy was averaged over the entire cycle to minimize any effects caused by errors in completely filling the fuel tanks. The bus was tested with no additional weight added to simulate passengers.

The engine calibration used for the vehicle road testing was the $1.0 \mathrm{~g} / \mathrm{bhp}-\mathrm{hr} \mathrm{NO}_{\mathrm{x}}$ calibration developed from the FTP emissions testing. SwRI decided that this calibration would be used for the demonstration, since it gave the best tradeoff between cycle emissions and efficiency. 
NREL ENVIROBUS 2000 TEST ROUTE

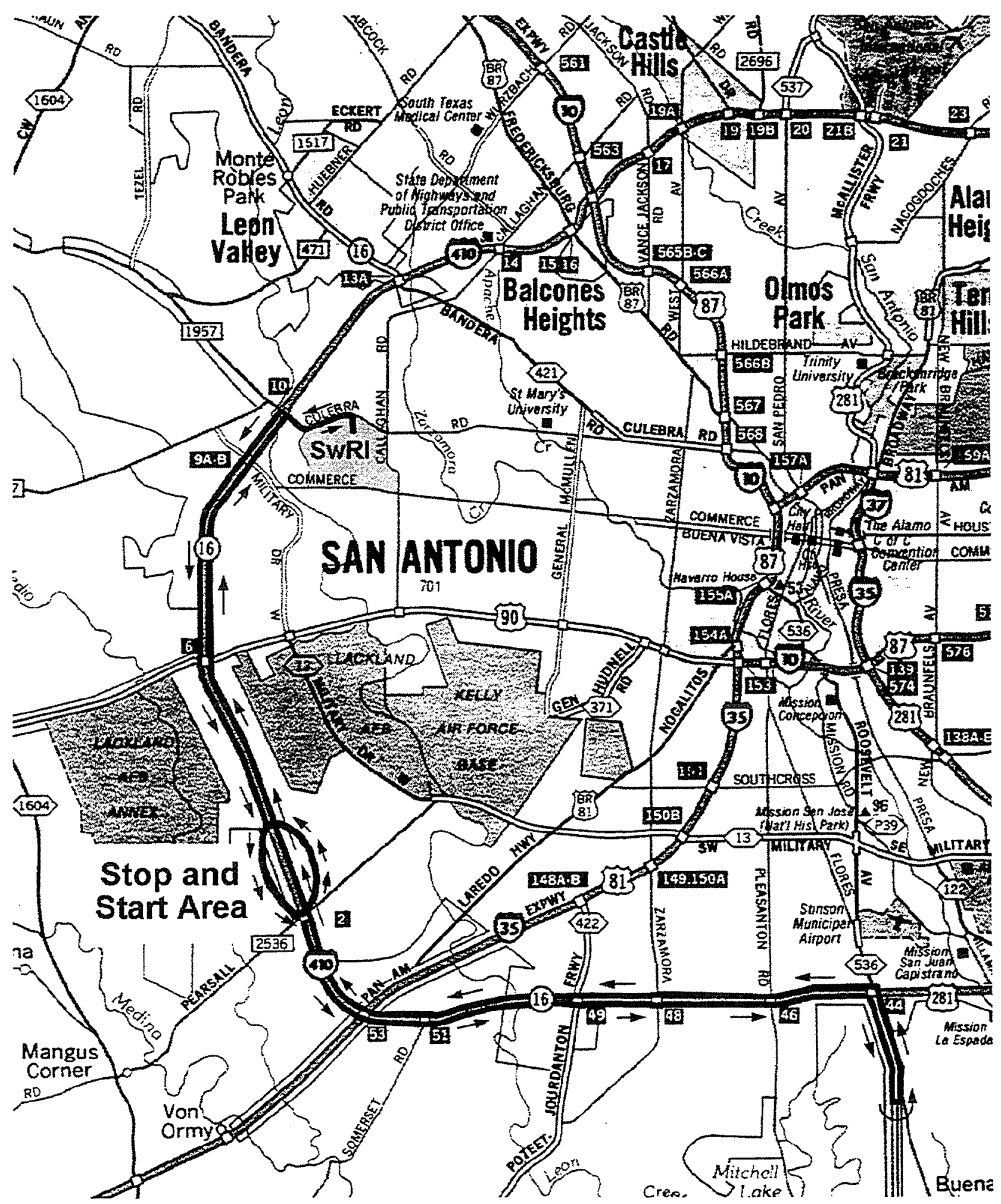

Figure 20. Driving route followed by bus during demonstration test 


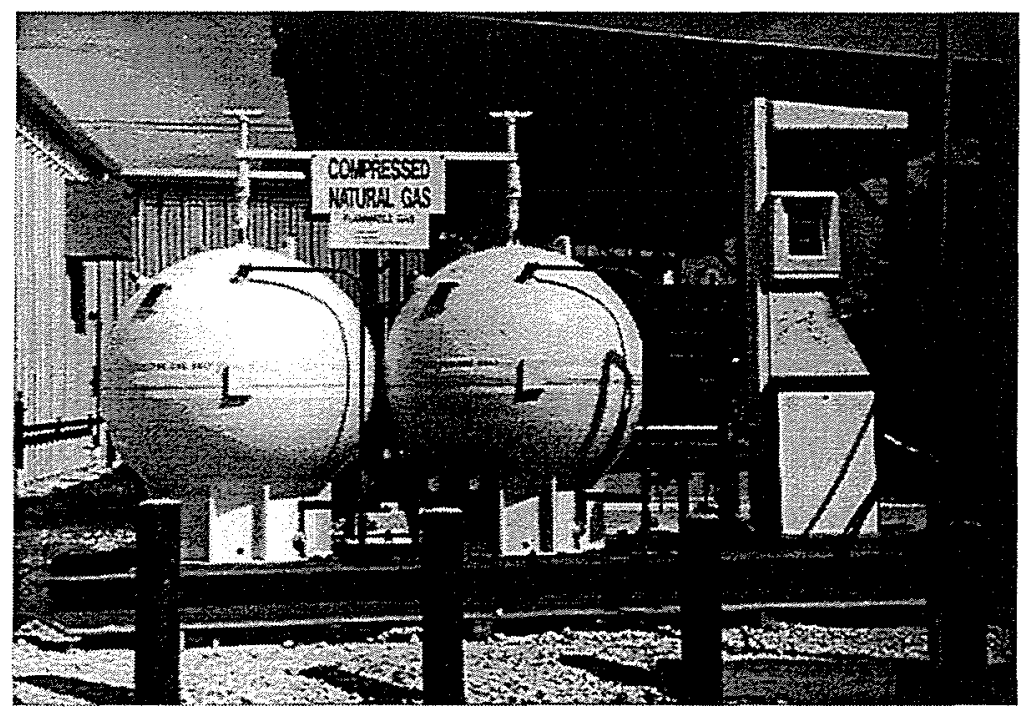

Figure 21. CNG refueling station located at SwRI

\subsubsection{Road Test Results}

The bus and engine accumulated 10,004 miles without encountering any problems. Fuel economy was calculated on an energy equivalent basis, assuming the following values:

1 "gallon" CNG $=5.67 \mathrm{lbs}$ (based on calibration data)

Lower heating value of $\mathrm{CNG}=20,500$ Brittish thermal units (Btu) (average for natural gas at SwRI) Lower heating value of diesel fuel $=18,270 \mathrm{Btu}^{*}$

Specific gravity of diesel fuel $=0.835^{*}$

* (data from Bosch Automotive Handbook)

Using these values in the following equation,

$$
1 \text { gallon }_{\mathrm{CNG}} * \frac{5.67 \mathrm{lbm}_{\mathrm{CNG}}}{1 \text { gallon }_{\mathrm{CNG}}} * \frac{20500 \mathrm{Btu}}{1 \mathrm{lbm}_{\mathrm{CNG}}} * \frac{1 \mathrm{lbm}_{\text {diesel }}}{18270 \mathrm{Btu}} * \frac{1 \text { gallon }_{\text {diesel }}}{6.97 \mathrm{lbm}_{\text {diesel }}}=0.91 \text { gallons }_{\text {diesel }}
$$

Table 9 summarizes the mileage data obtained for the bus during the demonstration test.

Table 9. Envirobus 2000 mileage data

\begin{tabular}{||c|c|c|c||}
\hline $\begin{array}{c}\text { Miles } \\
\text { Accumulated }\end{array}$ & $\begin{array}{l}\text { Measured } \\
\text { CNG } \\
\text { "Gallons" }\end{array}$ & $\begin{array}{c}\text { Diesel } \\
\text { Equivalent } \\
\text { Gallons }\end{array}$ & $\begin{array}{c}\text { Diesel } \\
\text { Equivalent Mileage } \\
\text { (miles/gallon) }\end{array}$ \\
\hline \hline 10,004 & $1,301.6$ & $1,188.1$ & 8.42 \\
\hline
\end{tabular}


The mileage obtained, 8.42 miles per gallon diesel equivalent, is very good. This reconfirms the high efficiency of the engine calibration developed.

\subsubsection{Repeat Chassis Dynamometer Tests}

Following the completion of the 10,000-mile demonstration test, the bus was returned to the chassis dynamometer facility for retesting. Due to the good performance shown by the bus during demonstration test, no changes were made to the engine calibration. Therefore, a direct comparison could be made between the results obtained before and after the demonstration test.

\subsubsection{Test Sequence}

Two sets of runs were conducted with the engine using the $1.0 \mathrm{~g} / \mathrm{bhp}$-hr calibration chip for all the tests. The first set of runs were a cold-start/hot-start HDCC sequence followed by a hot-start CBD cycle. The bus was equipped with the standard catalyst/muffler combination, as in the chassis tests described earlier. The second set of runs was designed to determine the ability of the new catalyst to reduce $\mathrm{HCHO}$ emissions. In order to achieve additional reductions in $\mathrm{HCHO}$ emissions, a new oxidation catalyst was purchased from Miratech, an industrial catalyst firm that has supplied SwRI with excellent catalysts in the past. Miratech recommended their proprietary catalyst due to its high activity for oxidizing formaldehyde at the expected exhaust gas temperatures. Use of this catalyst is discussed later in the results section.

\subsubsection{Test Results}

The results of these tests are shown in Table 10. The humidity levels for this set of tests were higher than those during the initial chassis dynamometer tests. This is reflected by the large $\mathrm{NO}_{\mathrm{x}}$ correction factor values, varying from 1.14 to 1.35 . These wide swings in the $\mathrm{NO}_{\mathrm{x}}$ correction factor tend to complicate the data comparison between the first set of test results obtained before the road test and those obtained after the road test. However, note that the $\mathrm{NO}_{\mathrm{x}}$ emissions remained quite low. A more accurate comparison of the emissions results before and after the road testing can be made by comparing the raw $\mathrm{NO}_{\mathrm{x}}$ emissions from the vehicle. This is discussed in more detail in the following paragraph.

Table 10. Repeat chassis dynamometer emissions results

\begin{tabular}{||c|c|c|c|c|c||}
\hline $\begin{array}{c}\text { Cycle } \\
\text { Type }\end{array}$ & $\begin{array}{c}\mathbf{N O}_{\mathbf{x}} \\
(\mathbf{g} / \mathbf{m i})\end{array}$ & $\begin{array}{c}\text { NMHC } \\
(\mathbf{g} / \mathbf{m i})\end{array}$ & $\begin{array}{c}\text { CO } \\
(\mathbf{g} / \mathbf{m i})\end{array}$ & $\begin{array}{c}\mathbf{N O}_{\mathbf{x}} \text { Corr. } \\
\text { Factor }\end{array}$ & $\begin{array}{c}\text { Raw NO } \\
(\mathbf{g} / \mathbf{m i})\end{array}$ \\
\hline \hline HDCC (cold) & 3.56 & 0.558 & 0.87 & 1.14 & 3.12 \\
\hline \hline HDCC (hot) & 3.32 & 0.577 & 0.59 & 1.20 & 2.77 \\
\hline CBD (hot) & 3.72 & 0.678 & 0.27 & 1.35 & 2.76 \\
\hline \hline
\end{tabular}


A comparison between the results obtained from the tests conducted before the demonstration and the results from the tests conducted at the end of the demonstration is shown graphically in Figures 22-24. The figures represent the data comparison of all emissions data for the HDCC cold start, $\mathrm{HDCC}$ hot start, and CBD hot-start tests, respectively. The figures show corrected $\mathrm{NO}_{x}$ emissions rather than raw $\mathrm{NO}_{x}$ emissions. A further comparison of $\mathrm{NO}_{\mathrm{x}}$ emissions data, both raw and corrected, for both sets of testing (i.e., before and after the road test) is shown in Table 11. Note that the emissions tend to repeat fairly well, especially considering the change in ambient conditions between test conditions and the fact that deviations from the reference cycle are likely larger during the chassis dynamometer testing than during the FTP (engine dynamometer) emissions testing. The repeatable emissions results over the widely varying humidity conditions is evidence that the humidity compensation system was effective and functioning properly.

Table 11. Comparison of chassis dynamometer $\mathrm{NO}_{\mathrm{x}}$ emissions results

\begin{tabular}{|c|c|c|c|c|}
\hline $\begin{array}{l}\text { Cycle } \\
\text { Type }\end{array}$ & $\begin{array}{l}\text { Before/After } \\
\text { Road Test }\end{array}$ & $\begin{array}{l}\text { Corr. } \mathrm{NO}_{\mathrm{x}} \\
(\mathrm{g} / \mathrm{mi})\end{array}$ & $\begin{array}{l}\mathrm{NO}_{\mathrm{x}} \text { Corr. } \\
\text { Factor }\end{array}$ & $\underset{(\mathrm{g} / \mathrm{mi})}{\operatorname{Raw} \mathrm{NO}_{\mathrm{x}}}$ \\
\hline HDCC (cold) & Before & 3.69 & 1.01 & 3.65 \\
\hline HDCC (hot) & Before & 2.86 & 1.00 & 2.86 \\
\hline CBD (hot) & Before & 3.05 & 1.00 & 3.05 \\
\hline HDCC (cold) & After & 3.56 & 1.14 & 3.12 \\
\hline HDCC (hot) & After & 3.32 & 1.20 & 2.77 \\
\hline CBD (hot) & After & 3.72 & 1.35 & 2.76 \\
\hline
\end{tabular}

\subsubsection{Formaldehyde Emissions}

The final set of runs focused on reducing the level of $\mathrm{HCHO}$ emissions to a level below that of the ULEV standard. A baseline HDCC cycle was run, with the bus equipped with a blank catalyst/muffler (no catalyst material loading on the catalyst substrate). The new Miratech catalyst was then installed in place of the blank catalyst/muffler, and the test was rerun. The HCHO emissions for the two runs were $0.432 \mathrm{~g} / \mathrm{mile}$ for the baseline no-catalyst case and $0.017 \mathrm{~g} / \mathrm{mile}$ for the catalyst-equipped case. These data indicate that the catalyst had an $\mathrm{HCHO}$ conversion efficiency of 96 percent, well above the 88 percent required to reach the ULEV level. To confirm that the catalyst had reduced the $\mathrm{HCHO}$ emissions to an acceptable level, an additional calculation was made to convert $\mathrm{g} / \mathrm{mile}$ data to $\mathrm{g} / \mathrm{bhp}-\mathrm{hr}$ data. This was done using the following equation:

$$
\frac{\mathrm{HCHO}(\mathrm{g} / \mathrm{mi}) * \text { Distance }(\mathrm{mi})}{\text { Fuel Used }\left(\mathrm{g}_{\text {fuel }}\right)} * \frac{453.6 \mathrm{~g}_{\text {fuel }}}{\mathrm{lb}_{\mathrm{m}}} * \mathrm{BSFC}\left(\mathrm{lb}_{\mathrm{m}} / \mathrm{bhp}-\mathrm{hr}\right)=\mathrm{HCHO}(\mathrm{g} / \mathrm{bhp}-\mathrm{hr})
$$




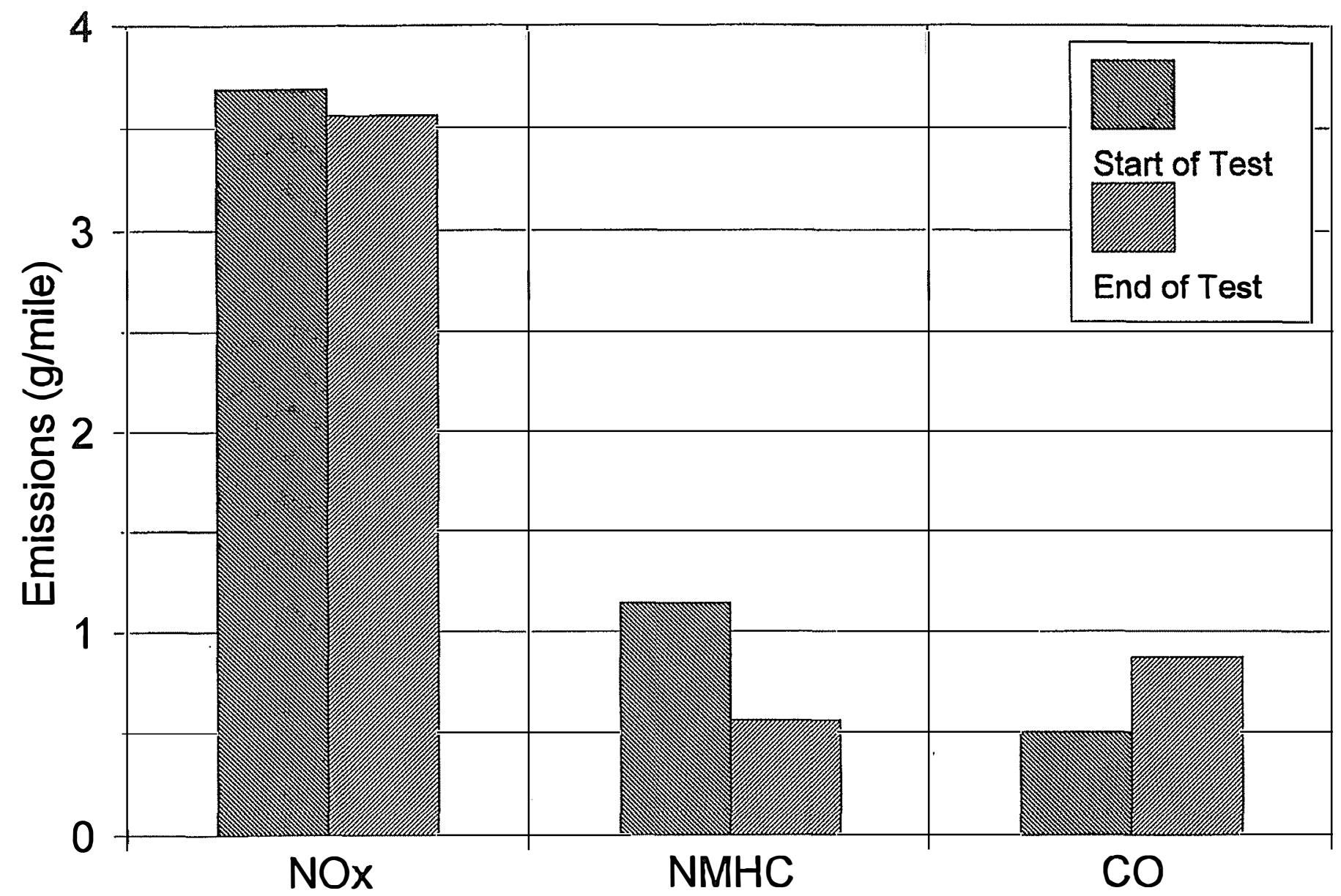

Figure 22. Comparison of emissions results for HDCC cold-start tests before and after demonstration test 


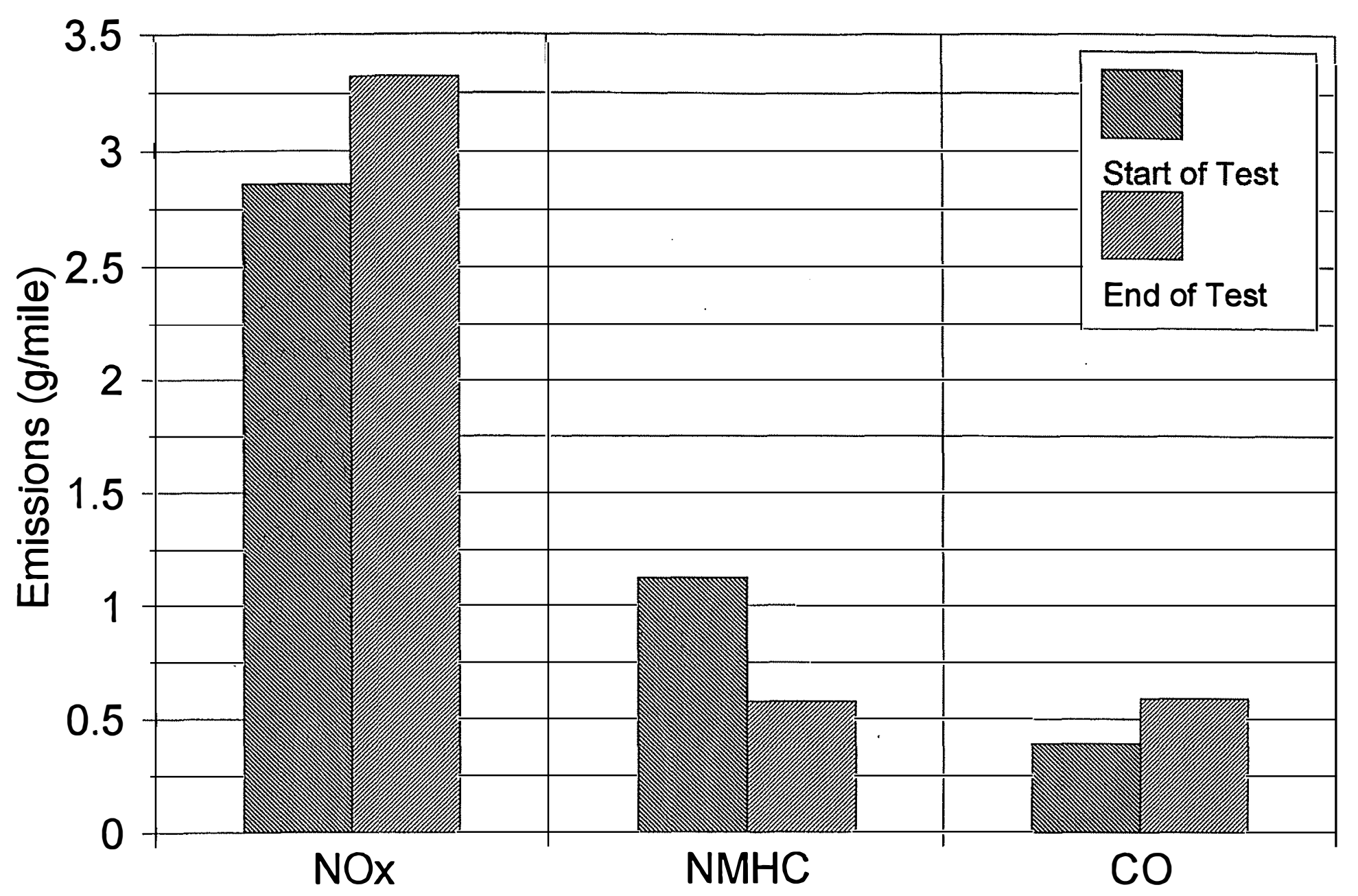

Figure 23. Comparison of emissions results for HDCC hot-start tests before and after the demonstration test 


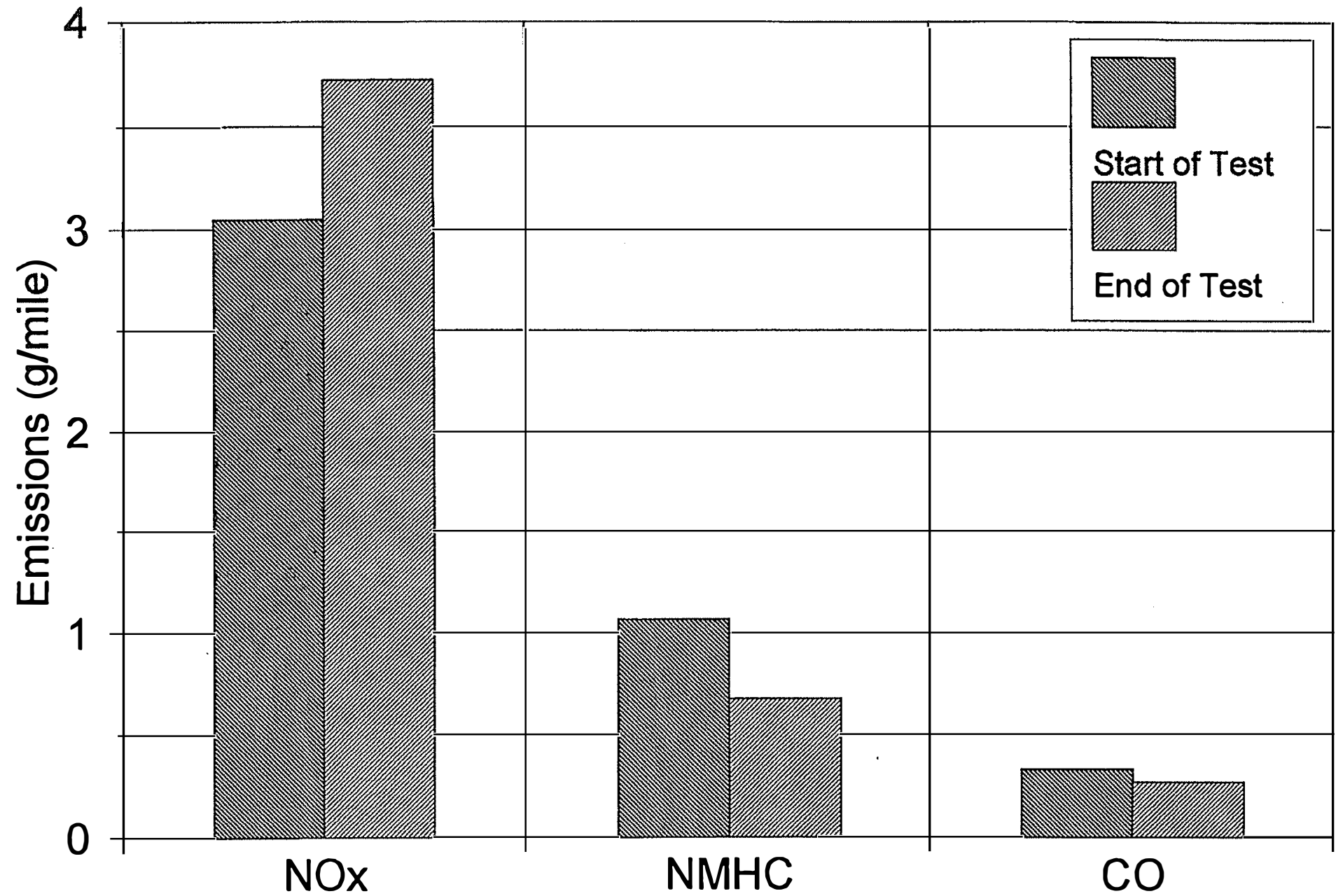

Figure 24. Comparison of emissions results for CBD hot-start tests before and after the demonstration test 
Assuming a BSFC $=0.403 \mathrm{lb} / \mathrm{bhp}-\mathrm{hr}$, the average obtained during the hot-start FTP transient tests with the $1.0 \mathrm{~g} / \mathrm{bhp}-\mathrm{hr} \mathrm{NO}$ calibration, the emissions for the baseline test were:

$$
0.432 \frac{\mathrm{g}_{\mathrm{HCHO}}}{\mathrm{mile}} * 5.483 \text { miles } * \frac{1}{1993.01 \mathrm{~g}_{\text {fuel }}} * 453.6 * 0.403=0.217 \frac{\mathrm{g}_{\mathrm{HCHO}}}{\mathrm{bhp}-\mathrm{hr}}
$$

*Note: In the process of determining the appropriate BSFC to use for the calculation, the engine operating over the HDCC chassis cycle was compared to the FTP cycle. From this investigation, SwRI determined that the two cycles are similar. Therefore, SwRI felt that the average BSFC value from the FTP testing would be appropriate for the calculation of the $\mathrm{HCHO}$ emissions. This assumption is supported by the following.

This value, $0.217 \mathrm{~g} / \mathrm{bhp}-\mathrm{hr}$, is in close agreement to the $0.200 \mathrm{~g} / \mathrm{bhp}-\mathrm{hr} \mathrm{HCHO}$ level obtained over the FTP test for a hot start cycle. Similarly, for the test using the Miratech catalyst, the HCHO emissions were:

$$
0.017 \frac{\mathrm{g}_{\mathrm{HCHO}}}{\text { mile }} * 5.490 \text { miles } * \frac{1}{2067.92 \mathrm{~g}_{\text {fuel }}} * 453.6 * 0.403=0.008 \frac{\mathrm{g}_{\mathrm{HCHO}}}{\mathrm{bhp}-\mathrm{hr}}
$$

This level, $0.008 \mathrm{~g} / \mathrm{bhp}-\mathrm{hr}$ is roughly one-third of the ULEV standard. From these data, a reasonable prediction can be made that the engine, when equipped with the Miratech catalyst, could easily attain all of the ULEV standards. 


\subsection{Other Activities}

\subsection{Railroad Commission of Texas Inspection}

An independent safety inspection of the onboard CNG fuel storage and handling system was conducted by the Railroad Commission of Texas (RCT) at the conclusion of the project. This safety inspection was comprehensive, involving a team of four inspectors working for several hours to inspect every component of the CNG system. The bus passed this inspection and is in full compliance with RCT safety regulations, which are more stringent than any other CNG standards, including the National Fire Protection Association 52. Only one minor change to the installation, (i.e., an alternative method of securing the CNG supply line where it passed through one of the chassis cross members), was recommended for further improvement of the bus design. This change was to provide more vibration damping and was made shortly after the inspection.

\subsection{Public Relations}

The bus was displayed at the Advanced Vehicle Showcase, which was held in conjunction with the Summit of the Eight meeting held in Denver, Colorado, on June 20-22, 1997. Blue Bird Corporation transported the bus to and from Denver. Representatives from all of the major project partners were in attendance at the event. Attending were Bill Horrell from John Deere, Dick Earl from Blue Bird, and John Kubesh from SwRI. 


\subsection{Conclusions}

This project provided some very good results regarding engine emissions and bus performance. The following conclusions can be drawn from the results:

(1) FTP transient emissions testing proved the low emissions characteristics of the engine. A $\mathrm{NO}_{x}$ emissions level of $1.0 \mathrm{~g} / \mathrm{bhp}$-hr was achieved along with low levels of NMHC, CO, and PM. With the exception of formaldehyde emissions, emissions at one-half the CARB ULEV level can be obtained without using a catalyst.

(2) The bus performed well throughout the demonstration period, with no maintenance of the bus or engine required. The fuel economy of the bus was also quite good, and the low emissions characteristics of the vehicle were confirmed through emissions testing on a chassis dynamometer.

(3) The integration of the laboratory-developed sensors, signal-conditioning hardware, and algorithms into the production controller was quite successful. The misfire detection system did not appear to be as practical as desired; however, the humidity compensation and surge suppression systems were quite successful. 


\subsection{Recommendations for Future Study}

Based on the outcome of this project, the following are recommendations for future study:

(1) Conduct another round of FTP transient testing with the engine equipped with the Miratech catalyst. Through these tests, an effort would be made to achieve the lowest practical $\mathrm{NO}_{x}$ and NMHC emissions levels, as well as officially document the overall $\mathrm{HCHO}$ emissions.

(2) Adapt the bus and engine for liquefied natural gas (LNG) operation. LNG is a logical fuel for heavy-duty vehicles that require a large fuel capacity or a long range. A demonstration of the practical use of LNG as a school bus fuel would be interesting. 


\title{
REPORT DOCUMENTATION PAGE
}

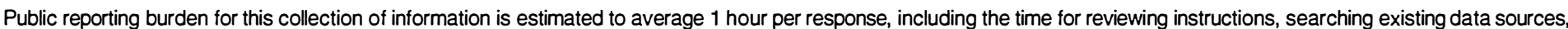

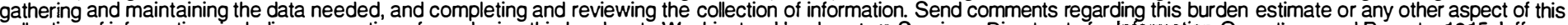

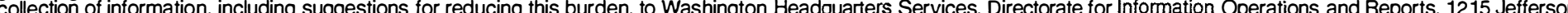

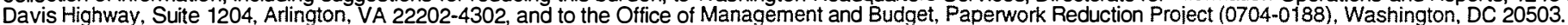

\begin{tabular}{l|l|l}
\hline 1. AGENCY USE ONLY (Leave blank) & 2. REPORT DATE & 3. REPORT TYPE AND DATES COVERED \\
& March 1998 & Subcontract report \\
\hline
\end{tabular}

\section{TITLE AND SUBTITLE}

5. FUNDING NUMBERS

Development of an Ultra-Safe, Ultra-Low Emissions Natural Gas Fueled School Bus: Final Report

(C) ZCF-5-13519-01

(TA) FU703230

\begin{abstract}
6. AUTHOR(S)
\end{abstract}
J. T. Kubesh

7. PERFORMING ORGANIZATION NAME(S) AND ADDRESS(ES)

Southwest Research Institute

6220 Culebra Road

San Antonio, TX 78238-5166

9. SPONSORING/MONITORING AGENCY NAME(S) AND ADDRESS(ES)

National Renewable Energy Laboratory

1617 Cole Boulevard

Golden, CO 80401-3393

8. PERFORMING ORGANIZATION REPORT NUMBER

\section{SUPPLEMENTARY NOTES}

\section{2a. DISTRIBUTION/AVAILABILITY STATEMENT}

National Technical Information Service

U.S. Department of Commerce

5285 Port Royal Road

Springfield, VA 22161 12b. DISTRIBUTION CODE

UC-1504

\section{ABSTRACT (Maximum 200 words)}

This report covers several significant areas of work. Integration of the engine technologies developed under Phase II into a production compressed natural gas engine is detailed, including information on the engine and control system modifications that were made. A demonstration of the emissions performance and durability of the integrated vehicle was also conducted, and emissions performance was quantified through emissions tests conducted while operating on a chassis dynamometer. Federal Test Procedure emissions results verifying the ultra-low emissions output of this engine are also included.

\section{SUBJECT TERMS}

Alternative fuels, compressed natural gas, ultra-safe technologies, ultra-low-emissions vehicles

15. NUMBER OF PAGES

45

16. PRICE CODE

\section{SECURITY CLASSIFICATION OF REPORT}

\section{SECURITY CLASSIFICATION OF THIS PAGE}

\section{SECURITY CLASSIFICATION OF ABSTRACT}

SPONSORING/MONITORING SENCY REPORT NUMBER

NRELSR-540-23842 